\title{
Study of plants traditionally used in public and animal health management in Seharti Samre District, Southern Tigray, Ethiopia
}

\author{
Solomon Araya ${ }^{1}$, Balcha Abera ${ }^{1}$ and Mirutse Giday ${ }^{2 *}$
}

\begin{abstract}
Background: In Ethiopia, medicinal plants have continued to play vital role in fulfilling human and livestock healthcare needs of different communities. However, these valuable resources are being depleted mainly due to agricultural expansion and deforestation. Therefore, immediate action is required to conserve these resources and document the associated knowledge. The purpose of this study was, thus, to document and analyze information associated with medicinal plants that are used in managing public and animal health problems in Seharti Samre District, Southern Tigray, Ethiopia.
\end{abstract}

Methods: Ethnobotanical data were collected from July 1, 2011 to December 30, 201 mainly using semi-structured interviews with informants sampled using purposive sampling technique and through field observations.

Results: The study revealed the use of 90 medicinal plant species in Seharti Samre District for the treatment of several human and livestock diseases. The plants belonged to 46 families and 82 genera. The majority of the medicinal plants were indicated to be harvested from the wild. Leaf was the most frequently harvested plant part accounting for $44 \%$ of the reported plants, followed by roots (16\%), whole plants (10\%) and seeds (8\%). The most widely used method of preparation was crushing (37\%), pounding (15\%) and chewing (13\%). Most medicinal plants were applied internally (64.6\%), followed by external application on the skin (35.4\%). Febrile illness is the disease group in the study area that scored the highest ICF value (0.97), followed by cardio-vascular problems (0.97) and evil eye (0.95). Different preference ranking exercises were also used to determine the most preferred and potential medicinal plants in the study area.

Conclusion: In Seharti Samre District, medicinal plants are still playing important role in the management of various human and livestock diseases, many of which are harvested for their leaf parts. However, activities of claimed medicinal plants need to be evaluated before recommending them for their wider use. Evaluation priority should be given to medicinal plants with the highest informant agreement as such plants are believed to have better activity.

Keywords: Medicinal plants, Preference ranking, Seharti Samre, Traditional medicine, Ethiopia

\section{Background}

The problem of health in African countries, including Ethiopia, is very acute as people have no full access to government and private health services. The absence or inaccessibility of modern healthcare services and other factors such as high cost of modern drugs and services

\footnotetext{
* Correspondence: mirutseg@yahoo.com

${ }^{2}$ Aklilu Lemma Institute of Pathobiology, Addis Ababa University, Addis Ababa, Ethiopia

Full list of author information is available at the end of the article
}

and better curing of herbal remedies against some chronic diseases has caused a large percentage of the population to rely on traditional medicine, and mostly on herbal remedies [1,2], for its primary health-care needs. In Africa, up to $80 \%$ of the population relys on traditional medicine to help meet its health care needs [3].

Ethiopia is a land of high variation in landscape, flora and fauna, multiplicity of ethnic groups with complex multicultural diversity, languages, cultures and beliefs 
which have in turn contributed to the high diversity of traditional knowledge and practices of the people including the use of medicinal plants. In Ethiopia, medicinal plants play important role in fulfilling human and livestock health care needs of different communities. Traditional use of medicinal plants has remained as the main alternative solution for different human and livestock health problems largely due to shortage of pharmaceutical products and modern health service stations, unaffordable prices of conventional drugs and drug resistance [4].

Today, many Ethiopian medicinal plants are facing extinction or severe genetic erosion mainly due to agricultural expansion, deforestation, over exploitation and destructive harvesting. Securidaca longipedenculata and Warburgia ugandensis are among the popular medicinal plants in Ethiopia that are being threatened due to over exploitation and destructive harvesting. Hagenia abysinica is another medicinal plant that is being depleted as a result of over exploitation [4]. For most of the threatened and endangered medicinal plants, no conservation action has been taken, and there is no even a complete inventory of these plants. Much of the knowledge on the uses of medicinal plants in the country is still held only by traditional societies and is usually transmitted verbally [5]. Unless the plants are conserved and the associated ethnomedicinal knowledge documented, there is a danger that both the valuable medicinal plants and the knowledge could vanish forever. As it is happening elsewhere in the country, medicinal plants of the Seharti Samre District of Tigray are facing the danger of being lost unless appropriate documentation and conservation measures are taken.

A number of ethnobotanical studies have previously been conducted in different parts of Tigray to document the use of medicinal plants [6-14]. For example, studies conducted by Teklay et al. [12], Abdurhman [9] and Zenebe et al. [13] reported the use of 114, 113 and 68 medicinal plants in Kilte Awlaelo, Ofla and Asgede Tsimbila districts, respectively. However, there is no record that indicates the documentation of medicinal plants used by the people of Seharti Samre District. The purpose of this study was, therefore, to document and analyze traditional knowledge of medicinal plants used to manage human and animal health problems in Seharti Samre District, Southern Tigray, Ethiopia.

\section{Methods}

\section{Description of the study area}

The study was conducted in Seharti Samre District (Woreda) located between $12^{0} 30^{\prime}$ and $13^{\circ} 02^{\prime}$ latitude north and $38^{\circ} 59^{\prime}$ and $39^{\circ} 26^{\prime}$ longitude east in south east of Tigray at about $57 \mathrm{~km}$ southwest of Mekelle, the capital city of Tigray Region and $820 \mathrm{~km}$ north of Addis
Ababa (Figure 1). The District has undulated type of landscape with altitude ranging from 1470 to 2370 meter above sea level (m.a.s.l) (Seharti Samre District Rural Agricultural Office, unpublished data of 2011). The District has warm and hot climate conditions and unimodal rainfall distribution that extends from April to September with the highest peak in July and August.

The great majority of inhabitants in the District belong to Tigray ethnic group. According to unpublished report of 2011 obtained from Seharti Samre District Health Office, the public healthcare coverage of the District reaches $85 \%$. However, there are people who still rely on traditional medicine due to low cost of the service and more preference to the system. A study by Yirga [8] reported the use of 27 medicinal plants in the neighbouring District of Enderta. In the District, there are five health centres and eighteen health posts. Pneumonia, skin diseases, malaria, intestinal parasites infection and diarrhoea, acute respiratory tract infection, gastritis, urinary tract infection, diarrhoea, snake bites and conjunctivitis are the top ten human health problems in the District (Seharti Samre District Health Office, unpublished report, 2011). Anthrax, black-leg, trypanosomiasis, bloat, gland swelling, cough and intestinal diseases are the major livestock diseases in the District (Seharti District Samre Veterinary Health Office, unpublished report, 2011).

\section{Selection of study sites}

The study was conducted in Seharti Samre District from July 1, 2011 to December 30, 2012. Prior to conducting this study, proposal approval letter was received from Jimma University Ethical Review Committee (ERC) and verbal informed consent from each informant who participated in the study.

\section{Sampling of informants}

Purposive sampling method was employed to select 66 traditional healers and knowledgeable individuals (55 men and 11 women) between the ages of 20 and 76 years for semi-structured interviews. Informants that were involved in preference/priority and direct matrix rankings were selected randomly from those healers and knowledgeable individuals that were already sampled for the interviews.

\section{Collection of data and plant specimens}

Semi-structured interviews and field observation $[15,16]$ were employed to collect ethnobotanical data. Individual interviews were held with informants to gather data on medicinal plants with regards to plants parts used, methods of preparation, dosage, route of administration, diseases treated, threats, conservation status, cultivation practice, marketability, acquisition/transfer of indigenous 


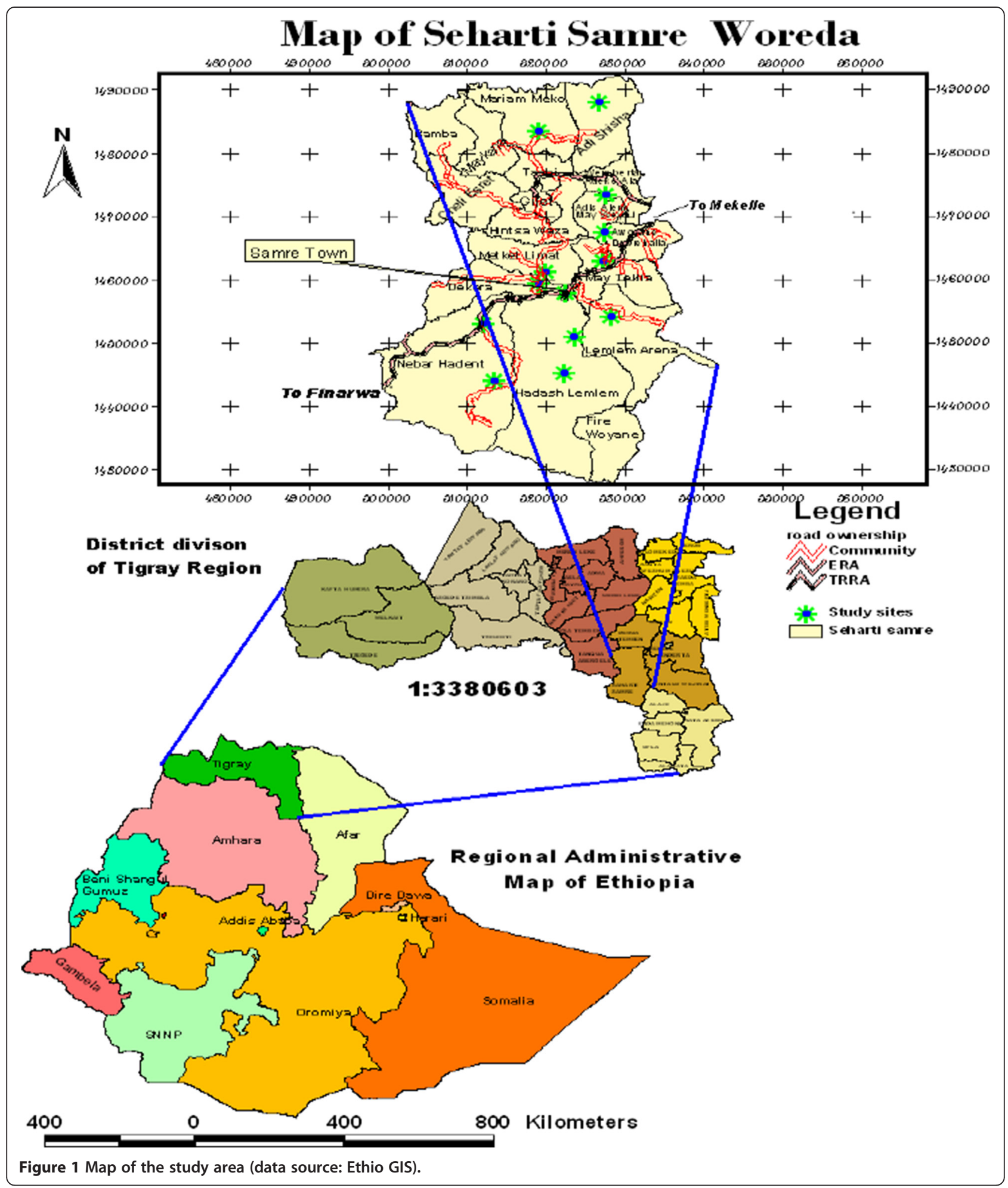

knowledge and attitudes of people towards using such plants. All communications with informants were held in Tigrigna, the official language of Tigray Region. Specimens of medicinal plans were collected, dried and identified with the help of botanists at Aklilu Lemma Institute of Pathobiology and the National Herbarium, Addis Ababa University (AAU) and were deposited at the Jimma University Herbarium. 


\section{Data analysis and presentation}

Microsoft Excel spreadsheet software was employed for organizing and analysis of ethnobotanical data. Descriptive statistical analysis was employed to determine the number of medicinal plants used and ailments treated in the study District, the most frequently used plant parts, main routes of remedy administration and to identify popular medicinal plants, main ways of knowledge acquisition/transfer, major habitats of the plants and their marketability.

Informant consensus factor (ICF) was calculated for each ailment group to estimate level of agreement among informants in the selection of plants against a given category. ICF was calculated using the formula ICF $=\frac{n u r-n t}{n u r-1}$ [17] where ICF stands for informant consensus factor, nur for number of use citations in each category and $n t$ for number of species used.

Preference ranking technique [18] was used to identify the most preferred medicinal plants used in the District to treat snake bite based on informants' personal preference or perception. Snake bite is one of the ten most important human health problems in the District. It is also among the ten diseases with the highest ICF values. The most preferred plant was assigned the highest score (6), while the least effective one was given the lowest value (1). For this purpose, eight individuals were randomly selected from the people that had already served as key informants. Each informant was provided with fresh specimens of six medicinal plants having the highest frequency of report by informants for being used to treat snake bite. The informants were then asked to rank the plants according to their degree of preference.

Priority ranking exercise [18] was also performed by seven informants to rank different factors perceived as threats to medicinal plants in the study area based on level of destructive impacts. During exercises, informants assigned values 1-4, 1 for the least destructive threat and 4 for the most destructive one.

Direct matrix ranking $[16,18]$ was performed for six commonly reported multipurpose medicinal plants. Based on the relative benefits obtained from each plant, a group of five informants were asked to discuss and assign, to each attribute, a value between 1 and 4 ( 1 for the lowest value and 4 for the highest value). Scores were then added and plants ranked.

\section{Results}

\section{Acquisition/transfer of medicinal plants knowledge}

Majority (65.6\%) of informants reported that transfer of knowledge on medicinal plants in the study District took place along the family line, from parents to children. Some informants (21.2\%) reported close relatives as sources of knowledge while other informants (9.1\%) indicated transfer of the knowledge on payment (9.1\%) and few reported acquisition of knowledge through trial and error methods (6.1\%). Results of interviews also revealed that $69.7 \%$ of the informants were willing to transfer their knowledge of medicinal plants along the family line verbally and $9.1 \%$ reported that they were happy to transfer the knowledge verbally assisted by practical demonstration. Other informants (21.2) reported that they had no interest to transfer their knowledge at all.

\section{Comparison of medicinal plant knowledge between age groups}

Analysis was made to compare medicinal plant knowledge among two age groups Result revealed that members belonging to the age group above 40 year reported an average of 2 medicinal plants while those belonging to the age group between 20 and 40 years reported an average of less one medicinal plant. During interviews and field visits, informants above 40 years of age were found to be very conversant on how to collect plants, process remedies and administer them. Besides, older informants had stronger belief in the curative effect of their medicinal plants as compared to the younger generation.

\section{Medicinal plants reported and diseases treated}

Ninety medicinal plant species that were used for the treatment of 51 human (Table 1) and 25 animal diseases (Table 2) were reported by the informants in Seharti Samre District. Of the total medicinal plants, 62 were used to treat human diseases only, 25 to treat both human and animal diseases and three to mange animal diseases only. The medicinal plants belonged to 46 families and 82 genera. The family Solanaceae was represented by 9 species, Lamiaceae by 8 species, Fabaceae by 6 species, Asteraceae and Euphorbiaceae by 5 species each, Malvaceae by 4 species, Boraginaceae and Capparidaceae by 3 species each. The families Rutaceae, Asclepiadaceae, Apocynaceae, Brassicaceae, Cucurbitaceae, Oleaceae, Rhamnaceae and Vitaceae contributed 2 species each and the remaining 28 families were represented by one species each. Most of the recorded medicinal plants were shrubs and herbs accounting for $42.2 \%$ and $39 \%$, respectively, followed by trees (14.4\%) and climbers (4.4\%).

Relatively higher numbers of medicinal plants were used to treat intestinal parasites; diarrhoea and stomach ache (26 species), wounds, scabies and leprosy (23 species), respiratory disease (16 species), evil eye, evil spirit, devil sickness (15 species) and rheumatism and arthritis (15 species).

Plant part (s) and methods used in preparation of remedies Leaves were the most preferred plants parts used in the preparation of remedies (44\%), followed by roots (16\%), 
Table 1 List of medicinal plants used to treat human diseases

\begin{tabular}{|c|c|c|c|c|c|c|c|c|}
\hline Scientific name & Family & Local name & Habit & Parts used & Disease treated & Mode of preparation and administration & $\begin{array}{l}\text { Application } \\
\text { route }\end{array}$ & $\begin{array}{l}\text { Voucher } \\
\text { no }\end{array}$ \\
\hline \multirow[t]{2}{*}{ Achyranthes aspera L. } & Amaranthaceae & mechelo & Herb & Root & Arthritis & $\begin{array}{l}\text { Roots chopped into pieces; seven pieces are put } \\
\text { on clean thread and tied on the waist until } \\
\text { recovered from the disease }\end{array}$ & Dermal & SA01303 \\
\hline & & & & Leaf & Herpes zoster & $\begin{array}{l}\text { Leaves roasted on metal plate, pounded into } \\
\text { powder, mixed with pure butter and smeared } \\
\text { on affected part }\end{array}$ & Dermal & \\
\hline \multirow[t]{2}{*}{$\begin{array}{l}\text { Acokanthera schimperi (A.DC.) } \\
\text { Schweinf. }\end{array}$} & Apocynaceae & Mebtie (merez) & Tree & Leaf & Jaundice & $\begin{array}{l}\text { Leaves are boiled in water for an hour and the } \\
\text { patient takes a cup of the solution per day for } \\
\text { seven days }\end{array}$ & oral & SA01333 \\
\hline & & & & & Wound & $\begin{array}{l}\text { Leaves are crushed and paste smeared on } \\
\text { affected part }\end{array}$ & Dermal & \\
\hline \multirow[t]{5}{*}{ Allium sativum $L$. } & Alliaceae & Tsa'da shegurti & Herb & Bulb & Gastritis & Bulb is eaten with flatbread locally known as 'enjera' & oral & SA01368 \\
\hline & & & & & Evil eye & Smelling aroma of bulb & Nasal & \\
\hline & & & & & Wound & $\begin{array}{l}\text { Bulbs are crushed, squeezed and wound washed } \\
\text { with the liquid until healed }\end{array}$ & Dermal & \\
\hline & & & & & Ring worm & Rubbing affected area with bulb & dermal & \\
\hline & & & & & Malaria & $\begin{array}{l}\text { Bulb of Allium sativum, Artemisia afra, Ruta } \\
\text { chalepensis and Lepidium sativum are crushed } \\
\text { together and paste taken for five-seven days }\end{array}$ & oral & \\
\hline \multirow[t]{5}{*}{ Aloe megalacantha Baker } & Alloaceae & Ere & Shrub & Exudate & Malaria & $\begin{array}{l}\text { Exudate, mixed with honey, is taken orally with } \\
\text { coffee cup for three days }\end{array}$ & oral & SA01384 \\
\hline & & & & & Diabetes & $\begin{array}{l}\text { Coffee cup of exudate taken every morning for } \\
\text { long period of time }\end{array}$ & oral & \\
\hline & & & & & Impotence & Smearing penis with exudate & Dermal & \\
\hline & & & & & Dandruff & Exudate smeared on head skin for a week & Dermal & \\
\hline & & & & & wound & Exudates smeared on wound & & \\
\hline $\begin{array}{l}\text { Alysicarpus ferrugineus } \\
\text { Hochst. \& Steud. ex A. Rich. }\end{array}$ & Fabaceae & $\begin{array}{l}\text { Hambo hambo } \\
\text { bita }\end{array}$ & Herb & Root & Jaundice & Root chewed for five days & oral & SA01336 \\
\hline \multirow[t]{2}{*}{ Argemone mexicana $\mathrm{L}$. } & Papaveraceae & Medafe tilian & Herb & Leaf & wound & $\begin{array}{l}\text { Fresh leaves are collected, crushed and paste } \\
\text { applied on affected part }\end{array}$ & Dermal & SA01381 \\
\hline & & & & & eczema & $\begin{array}{l}\text { Argemone mexicana leaves crushed and powder } \\
\text { sprayed on affected part. After two days, leaves } \\
\text { of Dodonaea angustifolia roasted on iron sheet, } \\
\text { pounded into powder are again sprayed on } \\
\text { affected part }\end{array}$ & Dermal & \\
\hline \multirow[t]{2}{*}{ Artemisia afra Jacq. ex willd. } & Asteraceae & Chena baria & Herb & Leaf & Evil eye & Aroma of the leaves help in expelling evil eye & nasal & SA01309 \\
\hline & & & & & Evil eye & $\begin{array}{l}\text { Leaves of Artemisia afar and Ruta chalepensis and } \\
\text { bulb of Allium sativum are crushed and aroma sniffed }\end{array}$ & nasal & \\
\hline
\end{tabular}


Table 1 List of medicinal plants used to treat human diseases (Continued)

\begin{tabular}{|c|c|c|c|c|c|c|c|c|}
\hline \multirow[t]{2}{*}{ Asparagus africanus Lam. } & \multirow[t]{2}{*}{ Asparagaceae } & \multirow[t]{2}{*}{ Kasta ansti } & \multirow[t]{2}{*}{ Shrub } & \multirow[t]{2}{*}{ Root } & impotence & $\begin{array}{l}\text { Roots are pounded into powder, mixed with meat } \\
\text { soup and vegetable and taken every evening for } \\
\text { a month }\end{array}$ & oral & \multirow[t]{2}{*}{ SA01340 } \\
\hline & & & & & Evil eye & $\begin{array}{l}\text { Root of Carissa spinarum and leaves of Ruta } \\
\text { Chalepensis, Artemisia afra, Cucumis ficifolius and } \\
\text { Asparagus africanus are crushed and fumigated } \\
\text { indoor }\end{array}$ & nasal & \\
\hline Boscia salicifolia Oliv. & Capparidaceae & Shesha & Shrub & Leaf & Ear infection & $\begin{array}{l}\text { Leaves are crushed, squeezed and liquid filtered } \\
\text { with clean cotton and three drops are applied } \\
\text { on infected ear }\end{array}$ & ear & SA01329 \\
\hline Cadaba rotundifolia Forssk. & Capparidaceae & Mora & Shrub & Leaf & toothache & Chew leaves and hold paste on affected tooth & oral & SA01328 \\
\hline \multirow[t]{6}{*}{ Calotropis procera (Ait.) Ait. } & \multirow[t]{6}{*}{ Asclepiadaceae } & \multirow[t]{6}{*}{ Ginda } & \multirow[t]{6}{*}{ Shrub } & Flower & Kidney stone & $\begin{array}{l}\text { Dry flower crushed into powder and mixed with } \\
\text { dough of wheat and medicine prepared tablet } \\
\text { form is baked on iron plate and three to four } \\
\text { tablets are taken for long period of time }\end{array}$ & oral & SA01375 \\
\hline & & & & \multirow[t]{4}{*}{ Latex } & Haemorrhoids & Latex is smeared on affected area & Dermal & \\
\hline & & & & & Wart & Cover the first appearing wart with latex & Dermal & \\
\hline & & & & & Scabies & smear whole affected area with latex & Dermal & \\
\hline & & & & & wound & Dress wound with latex & Dermal & \\
\hline & & & & Root & Tuberculosis & $\begin{array}{l}\text { Roots of C. procera is crushed into powder and } \\
\text { mixed with pounded bark of Croton macrostachyus } \\
\text { and leaves of Ficus palmata and sniffed }\end{array}$ & nasal & \\
\hline \multirow[t]{2}{*}{ Calpurnia aurea (Alt.) Benth. } & \multirow[t]{2}{*}{ Fabaceae } & \multirow[t]{2}{*}{ Hetsawets } & \multirow[t]{2}{*}{ Tree } & \multirow[t]{2}{*}{ Seed } & Gonorrhoea, syphilis & $\begin{array}{l}\text { Seeds are roasted on iron sheet, ground into } \\
\text { powder, mixed with honey, prepared in the form } \\
\text { of tablet and three tablets are taken every day } \\
\text { for five days. As a side effect, it causes headache }\end{array}$ & oral & \multirow[t]{2}{*}{ SA01345 } \\
\hline & & & & & Amoebiasis & $\begin{array}{l}\text { Seeds are roasted on iron sheet, ground into } \\
\text { powder, mixed with honey, dissolved in cup of } \\
\text { water and taken for three days }\end{array}$ & oral & \\
\hline Capparis tomentosa Lam. & Capparidaceae & Andiel & Shrub & Root & Evil eye & Patient fumigates himself with smoke of burning root & & SA01337 \\
\hline \multirow[t]{3}{*}{ Carissa spinarum (Forssk.) Vahl. } & \multirow[t]{3}{*}{ Apocynaceae } & \multirow[t]{3}{*}{ Agam } & \multirow[t]{3}{*}{ Shrub } & Root & Evil eye & $\begin{array}{l}\text { Crushed root is fumigated on a clay plate to expel } \\
\text { evil eye }\end{array}$ & Nasal & \multirow[t]{3}{*}{ SA01316 } \\
\hline & & & & Leaf & Febrile illness & $\begin{array}{l}\text { Leaves are crushed, squeezed and liquid taken } \\
\text { with coffee }\end{array}$ & oral & \\
\hline & & & & Fruit & Wound & $\begin{array}{l}\text { Fruits are crushed, dried, pounded into powder } \\
\text { and sprayed on wound }\end{array}$ & skin & \\
\hline \multirow[t]{2}{*}{ Chenopodium murale $\mathrm{L}$. } & \multirow[t]{2}{*}{ Chenopodiaceae } & \multirow[t]{2}{*}{$\begin{array}{l}\text { Hamedmado, } \\
\text { hamlikebbo }\end{array}$} & \multirow[t]{2}{*}{ Herb } & \multirow[t]{2}{*}{ Leaf } & Tetanus & $\begin{array}{l}\text { Leaves are crushed, mixed with butter, roasted on } \\
\text { metal plate and smeared on affected area before } \\
\text { covering it with cotton cloth. Application is } \\
\text { repeated three to four times within a week }\end{array}$ & Dermal & \multirow[t]{2}{*}{ SA01332 } \\
\hline & & & & & Vitiligo & $\begin{array}{l}\text { Leaves are crushed and pasted applied on affected } \\
\text { area }\end{array}$ & Dermal & \\
\hline
\end{tabular}


Table 1 List of medicinal plants used to treat human diseases (Continued)

\begin{tabular}{|c|c|c|c|c|c|c|c|c|}
\hline \multirow[t]{4}{*}{ Citrus lemon (L.) Burm. f. } & \multirow[t]{4}{*}{ Rutaceae } & \multirow[t]{4}{*}{ Lomin } & \multirow[t]{7}{*}{ Shrub } & \multirow[t]{4}{*}{ Fruit } & Haemorrhoids & $\begin{array}{l}\text { Fruits and leaves are pounded, mixed with butter } \\
\text { and applied on affected area }\end{array}$ & anal & \multirow[t]{4}{*}{ SA01369 } \\
\hline & & & & & Blood pressure & $\begin{array}{l}\text { Fruit juice is added into cup of water and drunk } \\
\text { every morning }\end{array}$ & oral & \\
\hline & & & & & cough & Fruit decoction with sugar added into it is taken orally & oral & \\
\hline & & & & & Tetanus & $\begin{array}{l}\text { Crushed fruit is mixed with butter and applied on } \\
\text { affected area and is covered with clean cotton }\end{array}$ & Dermal & \\
\hline \multirow[t]{3}{*}{$\begin{array}{l}\text { Clerodendrum myricoides (Hochst.) } \\
\text { R.Br. Ex Vatke }\end{array}$} & \multirow[t]{3}{*}{ Verbenaceae } & & & \multirow[t]{2}{*}{ Leaf } & Arthritis/rheumatism & $\begin{array}{l}\text { Apply butter on patient's head and let him/her } \\
\text { fumigated with leaves of the plant }\end{array}$ & nasal & \multirow[t]{3}{*}{ SA01347 } \\
\hline & & & & & $\begin{array}{l}\text { Conjunctivitis and } \\
\text { trachoma }\end{array}$ & $\begin{array}{l}\text { Leaves are crushed and added into boiling water } \\
\text { and the patient steam baths himself }\end{array}$ & ophthalmic & \\
\hline & & & & Root & Evil eye & $\begin{array}{l}\text { Roots are pounded into powder and sprinkled on } \\
\text { fire to expel evil eye }\end{array}$ & & \\
\hline \multirow[t]{3}{*}{ Coffea arabica L. } & \multirow[t]{3}{*}{ Rubiaceae } & \multirow[t]{3}{*}{ Buna } & \multirow[t]{3}{*}{ Shrub } & \multirow[t]{3}{*}{ Seed } & Amoebiasis & $\begin{array}{l}\text { Seeds are roasted, pounded into powder, mixed } \\
\text { with honey and taken orally }\end{array}$ & oral & \multirow[t]{3}{*}{ SA01397 } \\
\hline & & & & & wound & $\begin{array}{l}\text { Seeds are roasted, and pounded into powder and } \\
\text { paste applied on affected part }\end{array}$ & Dermal & \\
\hline & & & & & Fire burn & $\begin{array}{l}\text { Seeds are roasted, pounded into powder and paste } \\
\text { applied on affected area after mixing it with sap of } \\
\text { Aloe megalacantha }\end{array}$ & Dermal & \\
\hline Colutea abyssinica Jaub. and Spach. & Fabaceae & Qaqata & Shrub & Leaf & wound & $\begin{array}{l}\text { Leaves are pounded into powder and sprayed } \\
\text { on wound }\end{array}$ & Dermal & SA01342 \\
\hline $\begin{array}{l}\text { Commicarpus grandiflorus } \\
\text { (A. Rich.) Standl. }\end{array}$ & Nyctaginaceae & Ezni Tawa & Herb & Leaf & Furunclosis & $\begin{array}{l}\text { Leaves are crushed and paste smeared on affected } \\
\text { area }\end{array}$ & Dermal & SA01354 \\
\hline Commiphora schimperi (Berg) Engl. & Burseraceae & Anqa & Tree & Latex & wound & Latex smeared on wound & Dermal & SA01323 \\
\hline Cordia africana Lam. & Boragenaceae & Awhi & Tree & Leaf & febrile illness & $\begin{array}{l}\text { Leaves are crushed, squeezed and liquid taken } \\
\text { with coffee }\end{array}$ & oral & SA01367 \\
\hline \multirow[t]{6}{*}{ Croton macrostachyus Del. } & \multirow[t]{6}{*}{ Euphorbiaceae } & \multirow[t]{6}{*}{ Tanbuk } & \multirow[t]{6}{*}{ Tree } & Leaf & diarrhoea & $\begin{array}{l}\text { Leaves are crushed squeezed and a cup of juice } \\
\text { taken with honey }\end{array}$ & Oral & \multirow[t]{6}{*}{ SA01373 } \\
\hline & & & & Bark & Bloat & $\begin{array}{l}\text { A bark is dried, pounded into powder and one to } \\
\text { two spoons of powder are added into coffee or tea } \\
\text { and taken for a week }\end{array}$ & oral & \\
\hline & & & & Root & jaundice & $\begin{array}{l}\text { Root bark is dried, pounded into powder and two } \\
\text { to three spoons of powder are added into a cup } \\
\text { containing water. Treatment is taken for } 21 \text { days }\end{array}$ & oral & \\
\hline & & & & Leaf, bark & \multirow{2}{*}{$\begin{array}{l}\text { Sudden stomach } \\
\text { ache }\end{array}$} & \multirow{2}{*}{$\begin{array}{l}\text { Dried bark/leaves are pounded into powder, one to } \\
\text { two tea spoon of powder are added into skimmed } \\
\text { milk and served once }\end{array}$} & \multirow[t]{2}{*}{ oral } & \\
\hline & & & & Bark & & & & \\
\hline & & & & Leaf & Malaria & $\begin{array}{l}\text { Dried bark is pounded into powder, two to three } \\
\text { spoons of powder added into local beer and taken } \\
\text { for a week once per day. The medicine could cause } \\
\text { diarrhoea and vomiting }\end{array}$ & oral & \\
\hline
\end{tabular}


Table 1 List of medicinal plants used to treat human diseases (Continued)

\begin{tabular}{|c|c|c|c|c|c|c|c|c|}
\hline & & & & & scabies & $\begin{array}{l}\text { Leaves are crushed, mixed with butter and dressed } \\
\text { on affected part }\end{array}$ & Dermal & \\
\hline & & & & Leaf sap & Tinea versicolor & Sap of leaves are applied on affected area & Dermal & \\
\hline & & & & Leaf & Urine retention & $\begin{array}{l}\text { Leaves are added onto boiled water with sugar. } \\
\text { Solution is then taken every morning for seven days }\end{array}$ & oral & \\
\hline \multirow[t]{12}{*}{ Cucumis ficifolius A. Rich. } & \multirow[t]{12}{*}{ Cucurbitaceae } & \multirow[t]{12}{*}{$\begin{array}{l}\text { Ramboramb, lomin } \\
\text { bita }\end{array}$} & \multirow[t]{12}{*}{ Herb } & Leaf & Anthrax & $\begin{array}{l}\text { Leaves are either ground into powder or crushed, } \\
\text { squeezed, filtered, mixed with coffee and taken } \\
\text { with a coffee cup for two days }\end{array}$ & oral & SA01321 \\
\hline & & & & \multirow[t]{5}{*}{ Root } & Eye disease & Roots are chewed & oral & \\
\hline & & & & & Jaundice & Roots are chewed & oral & \\
\hline & & & & & Stomach ache & Roots are chewed & oral & \\
\hline & & & & & $\begin{array}{l}\text { Stomach ache } \\
\text { following delivery }\end{array}$ & Roots are chewed & oral & \\
\hline & & & & & Snake bite & Roots are chewed & oral & \\
\hline & & & & \multirow[t]{2}{*}{ Fruit } & Ear infection & $\begin{array}{l}\text { Three drops of fruit juice are applied into ear for } \\
\text { five days }\end{array}$ & ear & \\
\hline & & & & & Tuberculosis & Roots are chewed & oral & \\
\hline & & & & Root & Teeth ache & Roots are chewed & oral & \\
\hline & & & & Fruit & Asthma & $\begin{array}{l}\text { Fruits are washed, dried, ground into powder, } \\
\text { added onto boiled coffee and drunk }\end{array}$ & oral & \\
\hline & & & & Root, leaf & Eczema & $\begin{array}{l}\text { Roots and leaves are ground into powder, mixed } \\
\text { with honey and dressed on affected area }\end{array}$ & Dermal & \\
\hline & & & & Fruit/leaf & Tetanus & $\begin{array}{l}\text { Fruits and leaves are crushed, mixed with butter, } \\
\text { heated on fire and applied on affected area and } \\
\text { covered with clean cotton cloth. This is repeated } \\
\text { for three days }\end{array}$ & dermal & \\
\hline \multirow[t]{2}{*}{ Cucurbita pepo L. } & \multirow[t]{2}{*}{ Cucurbitaceae } & \multirow[t]{2}{*}{ Duba } & \multirow[t]{2}{*}{ Herb } & Seed & Tapeworm & $\begin{array}{l}\text { Seven roasted seeds are taken orally, followed by } \\
\text { three hours of fasting }\end{array}$ & oral & SA01390 \\
\hline & & & & Fruit & Urine retention & Fruits are cooked and taken as soup & oral & \\
\hline $\begin{array}{l}\text { Cynoglossum coeruleum Hochst. } \\
\text { ex A.DC. }\end{array}$ & Boraginaceae & Teng Begie & Herb & Leaf & Febrile illness (michi) & $\begin{array}{l}\text { Leaves are crushed, squeezed and liquid taken with } \\
\text { coffee or its lotion is applied on skin }\end{array}$ & $\begin{array}{l}\text { Oral or } \\
\text { dermal }\end{array}$ & SA01359 \\
\hline \multirow{2}{*}{$\begin{array}{l}\text { Cyphostemma adenocaule } \\
\text { (steud.ex A. Rich) Descoings ex } \\
\text { Wild and Drummond }\end{array}$} & \multirow[t]{2}{*}{ vitaceae } & \multirow[t]{2}{*}{ Aserkuka fetahkuka } & \multirow[t]{2}{*}{ Climber } & \multirow[t]{2}{*}{ Root } & Skull wound & $\begin{array}{l}\text { Dried roots are ground into powder, mixed with } \\
\text { butter and dressed on affected area }\end{array}$ & Dermal & \multirow[t]{2}{*}{ SA01346 } \\
\hline & & & & & Snake bite & Half of finger-sized root is chewed to detoxify poison & oral & \\
\hline \multirow[t]{2}{*}{ Datura stramonium L. } & \multirow[t]{2}{*}{ Solanaceae } & \multirow[t]{2}{*}{ mestenager } & \multirow[t]{2}{*}{ Herb } & \multirow[t]{2}{*}{ Leaf } & Tetanus & $\begin{array}{l}\text { Fresh leaves are crushed, mixed with butter, heated } \\
\text { and smeared on affected area before covering it } \\
\text { with clean cotton cloth }\end{array}$ & Dermal & \multirow[t]{2}{*}{ SA01312 } \\
\hline & & & & & Dandruff & Leaves are crushed and creamed on shaved head & Dermal & \\
\hline
\end{tabular}


Table 1 List of medicinal plants used to treat human diseases (Continued)

\begin{tabular}{|c|c|c|c|c|c|c|c|c|}
\hline & & & & \multirow[t]{2}{*}{ Seed } & Teeth ache & $\begin{array}{l}\text { Seeds are roasted on iron sheet and the patient } \\
\text { inhales smoke }\end{array}$ & Oral/nasal & \\
\hline & & & & & abortion & $\begin{array}{l}\text { Half tea spoon of seeds are ground into powder, } \\
\text { mixed with water and half of cup is drunk }\end{array}$ & oral & \\
\hline & & & & \multirow[t]{6}{*}{ Leaf } & Brain sharpness & $\begin{array}{l}\text { Leaves are crushed, squeezed, filtered and a cup } \\
\text { of juice is taken for some days }\end{array}$ & oral & \\
\hline & & & & & Leishmaniasis & Leaves are crushed and pasted on affected area & dermal & \\
\hline & & & & & Furunculosis & Leaves are crushed and pasted on affected area & Dermal & \\
\hline & & & & & Herpes zoster & $\begin{array}{l}\text { Leaves are roasted on iron sheet, pounded into } \\
\text { powder, mixed with butter and smeared on } \\
\text { affected area }\end{array}$ & Dermal & \\
\hline & & & & & Scabies & $\begin{array}{l}\text { Leaves are roasted on iron sheet, pounded into } \\
\text { powder, mixed with butter and smeared on } \\
\text { affected area }\end{array}$ & Dermal & \\
\hline & & & & & eczema & $\begin{array}{l}\text { Leaves are roasted on iron sheet and pounded in } \\
\text { to powder. After mixed with pure butter smeared } \\
\text { on affected area }\end{array}$ & Dermal & \\
\hline \multirow[t]{2}{*}{ Dodonaea angustifolia L. f. } & \multirow[t]{2}{*}{ Sapindaceae } & \multirow[t]{2}{*}{ Tahsos } & \multirow[t]{2}{*}{ Tree } & \multirow[t]{2}{*}{ Leaf } & Herpes zoster & $\begin{array}{l}\text { Leaves are roasted, ground into powder, mixed } \\
\text { with butter and smeared on affected area }\end{array}$ & Dermal & SA01327 \\
\hline & & & & & wound & Leaf powder is sprayed on wound & Dermal & \\
\hline $\begin{array}{l}\text { Erucastrum arabicum Drummond } \\
\text { and Hemsely }\end{array}$ & Brassicaceae & Hamli gudible & Herb & Leaf & Ring worm & Leaves are rubbed on skin & Dermal & SA01317 \\
\hline Erythrina abyssinica Lam. ex DC. & Fabaceae & $\begin{array}{l}\text { Zuwabue, enqui } \\
\text { hebey }\end{array}$ & Tree & Bark & Evil eye & $\begin{array}{l}\text { Put bark on fire and let patient to fumigate himself } \\
\text { with smoke }\end{array}$ & nasal & SA01322 \\
\hline \multirow[t]{2}{*}{ Eucalyptus globulus Labill. } & \multirow[t]{2}{*}{ Myrtaceae } & \multirow[t]{2}{*}{ Tsada Kelamitose } & \multirow[t]{2}{*}{ Tree } & \multirow[t]{2}{*}{ Leaf } & Febrile illness (michi) & The patient baths himself with steam of boiled leaves & Oral/nasal & SA01376 \\
\hline & & & & & Tinea pedis & $\begin{array}{l}\text { Leaves are boiled in water and the patient washes } \\
\text { his feet with the decoction }\end{array}$ & dermal & \\
\hline \multirow[t]{3}{*}{ Euclea divinorum Hiern. } & \multirow[t]{3}{*}{ Ebenaceae } & \multirow[t]{3}{*}{ Kuliew } & \multirow[t]{3}{*}{ Shrub } & Root & Scorpion bite & Roots are chewed to relieve pain & oral & SA01379 \\
\hline & & & & Root, stem & $\begin{array}{l}\text { Rheumatism and } \\
\text { arthritis }\end{array}$ & $\begin{array}{l}\text { The patient spreads animal butter on his/her head, } \\
\text { burn roots and stems on fire and baths him/herself } \\
\text { with smoke }\end{array}$ & Dermal & \\
\hline & & & & Root & Urine retention & Roots are chewed & oral & \\
\hline \multirow[t]{4}{*}{ Euphorbia cactus Boiss } & \multirow[t]{4}{*}{ Euphorbiaceae } & \multirow[t]{4}{*}{ Kolqual hamat } & \multirow[t]{4}{*}{ Shrub } & \multirow[t]{3}{*}{ Latex } & Leishmaniasis & Latex is smeared on affected area & Dermal & SA01386 \\
\hline & & & & & wound & Add few latex drops on wound & Dermal & \\
\hline & & & & & $\begin{array}{l}\text { Gonorrhoea and } \\
\text { syphilis }\end{array}$ & $\begin{array}{l}\text { Add three to four drops of latex on a piece of } \\
\text { 'enjera' and eat it. Medicine is taken for five } \\
\text { consecutive days. Overdose may cause diarrhoea } \\
\text { and vomiting }\end{array}$ & oral & \\
\hline & & & & Root & Jaundice & $\begin{array}{l}\text { Roots are ground into powder, mixed with honey } \\
\text { and taken for seven days }\end{array}$ & oral & \\
\hline
\end{tabular}


Table 1 List of medicinal plants used to treat human diseases (Continued)

\begin{tabular}{|c|c|c|c|c|c|c|c|c|}
\hline & & & & Latex & Ascariasis & $\begin{array}{l}\text { Four drops of latex are mixed with sugar solution } \\
\text { and taken once before diet }\end{array}$ & oral & \\
\hline & & & & & leprosy & Latex smeared on affected area & Dermal & \\
\hline Euphorbia petitiana A. Rich. & Euphorbiaceae & Demaito demu & Herb & Latex & Ring worm & Latex smeared on affected area & Dermal & SA01348 \\
\hline \multirow[t]{3}{*}{ Ficus palmata Forssk. } & \multirow[t]{3}{*}{ Moraceae } & \multirow[t]{3}{*}{ Beless } & \multirow[t]{3}{*}{ Tree } & \multirow[t]{3}{*}{ Latex } & Wart & Latex smeared on the first growing wart & Dermal & \multirow[t]{3}{*}{ SA01304 } \\
\hline & & & & & haemorrhoids & Latex smeared on affected area & Dermal & \\
\hline & & & & & Wound & Dress wound with latex & Dermal & \\
\hline Foeniculum vulgare Miller & Apiaceae & shelan & Herb & Whole plant & Urine retention & Take solution of the plant boiled in water & oral & SA01362 \\
\hline \multirow{3}{*}{$\begin{array}{l}\text { Gomphocarpus fruticosus (L.) } \\
\text { Aiton f. }\end{array}$} & \multirow[t]{3}{*}{ Asclepiadaceae } & \multirow[t]{3}{*}{ Demaito bereka } & \multirow[t]{3}{*}{ Herb } & Latex & Ringworm & Dress latex on affected area & Dermal & \\
\hline & & & & $\begin{array}{l}\text { Leaves, } \\
\text { stem }\end{array}$ & Arthritis & $\begin{array}{l}\text { Ground leaves and stems, mix powder with butter } \\
\text { and apply on affected body. Patient needs to } \\
\text { expose himself to sunlight for an hour }\end{array}$ & Dermal & \multirow[t]{2}{*}{ SA01343 } \\
\hline & & & & Root & Abortion & Chew the root & oral & \\
\hline Gossypium herbaceum L. & Malvaceae & Tut & Shrub & Root & Snake bite & Roots are chewed to detoxify poison & oral & SA01363 \\
\hline Hibiscus micranthus L.f & Malvaceae & Segot Hamat & Shrub & Whole plant & typhus & $\begin{array}{l}\text { House is fumigated with smoke to protect oneself } \\
\text { from the disease }\end{array}$ & nasal & \\
\hline Hypoestes forskaolii (Vahl) R. Br. & Acanthaceae & Gerbia & Herb & Leaf & jaundice & Leaves are crushed, squeezed and juice taken orally & & SA01315 \\
\hline \multirow{4}{*}{$\begin{array}{l}\text { Jasminum granditlorum L. subsp. } \\
\text { floribundum (R.Br. ex Fresen.) } \\
\text { P.S. Green }\end{array}$} & \multirow[t]{4}{*}{ Oleaceae } & \multirow[t]{4}{*}{ habitselim } & \multirow[t]{4}{*}{ Shrub } & \multirow[t]{4}{*}{ Leaf } & Ascariasis & $\begin{array}{l}\text { Leaves are crushed, squeezed and cup of juice } \\
\text { with sugar is taken orally }\end{array}$ & oral & \multirow[t]{4}{*}{ SA01326 } \\
\hline & & & & & tapeworm & $\begin{array}{l}\text { Leaves are crushed, squeezed and cup of juice } \\
\text { with sugar is taken orally }\end{array}$ & oral & \\
\hline & & & & & wound & $\begin{array}{l}\text { Leaves are roasted on iron sheet ground into powder } \\
\text { and are sprayed on wound }\end{array}$ & Dermal & \\
\hline & & & & & vomiting & Leaves are chewed to stop vomiting & oral & \\
\hline \multirow[t]{2}{*}{$\begin{array}{l}\text { Justicia schimperiana (Hochst. ex } \\
\text { A.Nees) T. Anders }\end{array}$} & \multirow[t]{2}{*}{ Acanthaceae } & \multirow[t]{2}{*}{ Shemeza } & \multirow[t]{2}{*}{ Shrub } & \multirow[t]{2}{*}{ Leaf } & Jaundice & $\begin{array}{l}\text { Seven leaves of } J \text {. schimperiana and seven leaves } \\
\text { of Croton mycrostachyus roasted on iron sheet, } \\
\text { crushed into powder are eaten with 'enjera' daily } \\
\text { for twenty-one days }\end{array}$ & oral & \multirow[t]{2}{*}{ SA01301 } \\
\hline & & & & & & $\begin{array}{l}\text { A cup of leaf juice of the plant is taken daily for } \\
\text { twenty-one days }\end{array}$ & oral & \\
\hline Klinia odora Forssk. & Asteraceae & Berier & Shrub & Whole plant & $\begin{array}{l}\text { Snake bite, evil } \\
\text { eye, evil spirit }\end{array}$ & $\begin{array}{l}\text { House is fumigated to repel snakes and expel } \\
\text { evil spirit }\end{array}$ & nasal & SA01378 \\
\hline \multirow{2}{*}{$\begin{array}{l}\text { Leonotis ocymifolia (Bunn. f.) } \\
\text { Iwarsson }\end{array}$} & \multirow[t]{2}{*}{ Lamiaceae } & \multirow{2}{*}{$\begin{array}{l}\text { Keyh Embeba } \\
\text { Ketater }\end{array}$} & \multirow[t]{2}{*}{ Herb } & \multirow[t]{2}{*}{ Whole plant } & Febrile illness (michi) & Fumigating oneself with smoke of plant & nasal & \multirow[t]{2}{*}{ SA01371 } \\
\hline & & & & & Eye disease & Fumigating oneself with smoke of plant & nasal & \\
\hline \multirow[t]{2}{*}{ Lepidium sativum L. } & \multirow[t]{2}{*}{ Brassicaceae } & \multirow[t]{2}{*}{ Shenfa } & \multirow[t]{2}{*}{ Herb } & Seed & $\begin{array}{l}\text { Amoebiasis and } \\
\text { diarrhoea }\end{array}$ & $\begin{array}{l}\text { Seeds are ground into powder, mixed with honey } \\
\text { and then taken for three days }\end{array}$ & Dermal & SA01310 \\
\hline & & & & & Gland TB & $\begin{array}{l}\text { Open swelling/wound, add small amount of sulphur } \\
\text { and covered it with seed paste of } L \text {. sativum and } \\
\text { latex of } C \text {. procera }\end{array}$ & Dermal & \\
\hline
\end{tabular}


Table 1 List of medicinal plants used to treat human diseases (Continued)

\begin{tabular}{|c|c|c|c|c|c|c|c|c|}
\hline & & & & & Evil spirit & $\begin{array}{l}\text { Grind seeds, add powder into water and spray } \\
\text { solution indoor to expel evil sprit }\end{array}$ & Dermal & \\
\hline & & & & & malaria & $\begin{array}{l}\text { L. sativum seeds are crushed with leaves of } \\
\text { R. chalepensis and A. Sativum and then taken orally } \\
\text { for seven days }\end{array}$ & Dermal & \\
\hline Premna oligotricha L. & Lamiaceae & Sasa hadima & Shrub & Leaf & Ascariasis & $\begin{array}{l}\text { Leaves are crushed and squeezed and a cup of } \\
\text { juice is taken once orally }\end{array}$ & & SA01325 \\
\hline \multirow[t]{2}{*}{ Linum usitatissimum L. } & Linaceae & Entatie & & Seed & Placental retention & $\begin{array}{l}\text { Seeds roasted on iron sheet and grinding into } \\
\text { powder, then cooked in the presence of honey } \\
\text { and taken for a month before delivery }\end{array}$ & oral & SA01386 \\
\hline & & & & & amoebiasis & $\begin{array}{l}\text { Seeds are ground, mixed with water and a cup of } \\
\text { juice drunk in the morning }\end{array}$ & oral & \\
\hline Lycopersicon esculentum Mill. & Solanaceae & Tsebhi Awun & Herb & Leaf & Anthrax & Leaves are crushed, mixed with honey and swallowed & oral & SA01352 \\
\hline \multirow[t]{2}{*}{ Maesa lanceolata Forssk. } & Myrsinaceae & Saira & Tree & Leaf & Scabies & Leaves are crushed and juice smeared on affected part & Dermal & SA01302 \\
\hline & & & & Seed & Tapeworm & $\begin{array}{l}\text { Seeds are ground, powder mixed with water and a } \\
\text { cup of juice taken orally once }\end{array}$ & oral & \\
\hline Malva verticillata $\mathrm{L}$. & Malvaceae & Enkeftiha & Herb & Leaf & Anthrax & Leaves are crushed, mixed with honey and swallowed & oral & SA01330 \\
\hline \multirow[t]{4}{*}{ Melia azedarach L. } & Meliaceae & Neem & Tree & Leaf & Tonsillitis & Crush leaves, filter and drunk the juice & oral & SA01382 \\
\hline & & & & Seed, leaf & Dandruff & $\begin{array}{l}\text { Seeds and leaves are crushed and paste applied on } \\
\text { head skin }\end{array}$ & Dermal & \\
\hline & & & & Leaf & Malaria & $\begin{array}{l}\text { Leaves are crushed and squeezed, and a cup of } \\
\text { solution taken orally daily for five days }\end{array}$ & oral & \\
\hline & & & & & Tooth decay & Leaves are chewed and spat & & \\
\hline \multirow[t]{3}{*}{$\begin{array}{l}\text { Meriandra dianthera (Roth, ex. } \\
\text { Roem. \& Schult.)Briq. }\end{array}$} & Lamiaceae & Mesaguh & Tree & Leaf & Blood pressure & $\begin{array}{l}\text { Leaves are boiled in water and solution taken daily } \\
\text { for a month by cup of tea until improvement }\end{array}$ & oral & SA01339 \\
\hline & & & & & Diarrhoea & $\begin{array}{l}\text { Leaves are ground, powder is mixed with water } \\
\text { and a cup of solution taken orally }\end{array}$ & oral & \\
\hline & & & & & malaria & $\begin{array}{l}\text { Leaves are crushed, squeezed and a cup of juice } \\
\text { taken daily for five days }\end{array}$ & & \\
\hline Nicotiana tabacum L. & Solanaceae & Tunbako & Herb & Root & Snake bite & $\begin{array}{l}\text { Roots are chewed or crushed and paste applied } \\
\text { on wound }\end{array}$ & oral & SA01308 \\
\hline $\begin{array}{l}\text { Ocimum lamiifolium. Hochst.Ex } \\
\text { Benth. }\end{array}$ & Lamiaceae & $\begin{array}{l}\text { Dem akher } \\
\text { (demekasie) }\end{array}$ & Shrub & Leaf & Febrile illness (michi) & $\begin{array}{l}\text { Leaves are crushed and solution drunk with coffee. } \\
\text { Juice is also smeared on skin }\end{array}$ & oral/dermal & SA01311 \\
\hline \multirow[t]{3}{*}{$\begin{array}{l}\text { Olea europaea L subsp. cuspidata } \\
\text { (Wall. ex G. Don) Cif. }\end{array}$} & Oleaceae & Awlie & Tree & Leaf & Asthma & $\begin{array}{l}\text { Leaves are boiled in water and a cup of solution } \\
\text { drunk every evening with skimmed milk to arrest } \\
\text { vomiting }\end{array}$ & oral & SA01374 \\
\hline & & & & & vomiting & Leaves are chewed to stop vomiting & oral & \\
\hline & & & & & Amoebiasis & $\begin{array}{l}\text { Leaves are crushed, squeezed and a cup of } \\
\text { taken orally }\end{array}$ & oral & \\
\hline
\end{tabular}


Table 1 List of medicinal plants used to treat human diseases (Continued)

\begin{tabular}{|c|c|c|c|c|c|c|c|c|}
\hline & & & & & Eye infection & $\begin{array}{l}\text { Leaves are crushed, squeezed, filtered and two to } \\
\text { three drops are added daily into the eye for five days }\end{array}$ & ophthalmic & \\
\hline & & & & & Teeth ache & Leaves are crushed and paste applied on affected area & Dermal & \\
\hline & & & & & Ascariasis & $\begin{array}{l}\text { Leaves are crushed, squeezed and a cup of juice } \\
\text { taken orally for one day }\end{array}$ & oral & \\
\hline $\begin{array}{l}\text { Ormocarpum pubescence (Hochst.) } \\
\text { Cuf. ex Gillett }\end{array}$ & Fabaceae & Alendia & Shrub & Stem & rheumatism & $\begin{array}{l}\text { Stems burned on prepared place at home and } \\
\text { females bathing the smoke putting butter on } \\
\text { their head }\end{array}$ & nasal & SA01320 \\
\hline Orobanche minor Smit. & Orobanchaceae & Selmi & Herb & Whole plant & Eye disease & $\begin{array}{l}\text { Burn the plant on clay dish and let the patient } \\
\text { fumigate himself with smoke }\end{array}$ & nasal & SA01338 \\
\hline Otostegia integrifolia Benth. & Lamiaceae & Chendog & Shrub & Leaf & Blood pressure & $\begin{array}{l}\text { Leaves are boiled boiling in water and a cup of } \\
\text { solution drunk every morning until recovery }\end{array}$ & oral & SA01357 \\
\hline \multirow[t]{2}{*}{ Oxalis anthelmintica A. Rich } & Oxalidaceae & Habachego & Herb & Leaf & Heart failure & leaves are eaten for long period of time (about a year) & oral & SA01318 \\
\hline & & & & & Tapeworm & $\begin{array}{l}\text { Patient eats some and remains on diet for next } \\
\text { three hours }\end{array}$ & oral & \\
\hline \multirow[t]{2}{*}{ Pavonia burchellii (DC.) Dyer. } & Malvaceae & Neger negarito & Shrub & Leaf & Stomach ache & $\begin{array}{l}\text { Leaves are crushed, squeezed and a cup of juice } \\
\text { taken orally }\end{array}$ & & SA01388 \\
\hline & & & & & cough & A cup of leaf juice is taken orally & & \\
\hline \multirow[t]{4}{*}{ Phytolacca dodecandra L'Herit. } & Phytolacaceae & Shebti & Shrub & Root & Rabies & $\begin{array}{l}\text { Dried root of the plant is powdered and mixed } \\
\text { with local alcohol and a cup of solution drunk } \\
\text { daily for twelve days. vomiting is its side effect } \\
\text { and, therefore, restricted to children and pregnant } \\
\text { women }\end{array}$ & oral & SA01387 \\
\hline & & & & Leaf & Gonorrhoea & $\begin{array}{l}\text { Leaves of } P \text {. dodecandra and roots of } C \text {. macrostachyus } \\
\text { are ground, powdered mixed with water and solution } \\
\text { drunk with one to two cups of coffee }\end{array}$ & oral & \\
\hline & & & & & Jaundice & $\begin{array}{l}\text { Leaves are crushed, squeezed and one cup of juice } \\
\text { taken daily for } 21 \text { days }\end{array}$ & oral & \\
\hline & & & & & scabies & $\begin{array}{l}\text { Crushed leaves are rubbed on the skin. Skin is then } \\
\text { washed in half -hour time }\end{array}$ & Dermal & \\
\hline \multirow[t]{2}{*}{ Plantago lanceolata $\mathrm{L}$. } & Plantaginaceae & Melhas kelbi & Herb & Leaf & Tinea corperis & Leaves are rubbed on affected area & Dermal & SA01358 \\
\hline & & & & & wound & $\begin{array}{l}\text { Leaves are crushed, squeezed and solution } \\
\text { applied on wound }\end{array}$ & Dermal & \\
\hline Plumbago zeylanica L. & Plumbaginaceae & Aftihi & Shrub & Root & $\begin{array}{l}\text { Evil eye, evil spirit, } \\
\text { magic }\end{array}$ & Roots are fumigated in the house & nasal & SA01324 \\
\hline \multirow[t]{3}{*}{ Polygala abyssinica Fres. } & Polygalaceae & Etselebona & Herb & Root & Snake bite & Roots are chewed & oral & SA01314 \\
\hline & & & & & Sharpen mind & $\begin{array}{l}\text { Finger-sized root is chewed. Overdose may } \\
\text { causes madness }\end{array}$ & oral & \\
\hline & & & & & $\begin{array}{l}\text { Sever stomach } \\
\text { ache }\end{array}$ & Roots are chewed & oral & \\
\hline
\end{tabular}


Table 1 List of medicinal plants used to treat human diseases (Continued)

\begin{tabular}{|c|c|c|c|c|c|c|c|c|}
\hline \multirow[t]{2}{*}{ Rhamnus prinoides L'Herit. } & \multirow[t]{2}{*}{ Rhamnaceae } & \multirow[t]{2}{*}{ Gesho } & \multirow[t]{2}{*}{ Shrub } & \multirow[t]{2}{*}{ Leaf } & Tonsillitis & $\begin{array}{l}\text { Mothers chewing the leaves and spit to mouth of } \\
\text { their children where as young ones chew it for } \\
\text { themselves }\end{array}$ & Dermal & \multirow[t]{2}{*}{ SA01350 } \\
\hline & & & & & Eczema & $\begin{array}{l}\text { Leaves crushed, mixed with pure butter and } \\
\text { dressing the affected part }\end{array}$ & Dermal & \\
\hline $\begin{array}{l}\text { Rhoicissus tridentata (L. f.) Wild \& } \\
\text { Drummond }\end{array}$ & Vitaceae & $\begin{array}{l}\text { Hareg temen } \\
\text { (etsezewie) }\end{array}$ & Climber & Root & Snake bite & $\begin{array}{l}\text { Less than a finger-sized root is chewed and } \\
\text { swallowed. Overdose causes severe stomach } \\
\text { ache and vomiting }\end{array}$ & oral & SA01344 \\
\hline \multirow[t]{3}{*}{ Rumex abyssinicus Jacq. } & \multirow[t]{3}{*}{ Polygonaceae } & \multirow[t]{3}{*}{ mokemoko } & \multirow[t]{3}{*}{ Herb } & \multirow[t]{3}{*}{ Root } & Blood pressure & $\begin{array}{l}\text { Roots are ground, powder mixed with water and } \\
\text { solution drunk with tea every morning until } \\
\text { improvement }\end{array}$ & oral & \multirow[t]{3}{*}{ SA01398 } \\
\hline & & & & & Cancer & $\begin{array}{l}\text { Root powder is mixed in spicy stew to increase } \\
\text { its power of curing the disease }\end{array}$ & oral & \\
\hline & & & & & Tooth ache & Chew root and apply paste on affected tooth & oral & \\
\hline \multirow[t]{4}{*}{ Rumex nervosus Vahl. } & \multirow[t]{4}{*}{ Polygonaceae } & \multirow[t]{4}{*}{ Huhot } & \multirow[t]{4}{*}{ Shrub } & Stem & gastritis & Young stems are chewed with salt and swallowed & oral & \multirow[t]{4}{*}{ SA01394 } \\
\hline & & & & Root & Snake bite & Roots are chewed to detoxify poison & oral & \\
\hline & & & & \multirow[t]{2}{*}{ Leaf } & Skin rash & Leaves are crushed and paste rubbed on affected area & Dermal & \\
\hline & & & & & Breast cancer & Leaves are crushed and paste applied on affected area & Dermal & \\
\hline Ricinus communis L. & Euphorbiaceae & Gulie & Shrub & Seed & Amoebiasis & $\begin{array}{l}\text { Crushed seeds are mixed with water and taken } \\
\text { with a cup of tea once }\end{array}$ & oral & SA01377 \\
\hline \multirow[t]{4}{*}{ Ruta chalepensis L. } & \multirow[t]{4}{*}{ Rutaceae } & \multirow[t]{4}{*}{ Chena adam } & \multirow[t]{4}{*}{ Herb } & \multirow[t]{4}{*}{ Leaf } & Evil eye & Rub the leaves and Smell & nasal & \multirow[t]{4}{*}{ SA01380 } \\
\hline & & & & & cough & Leaves boiled in milk are taken orally & oral & \\
\hline & & & & & Malaria & $\begin{array}{l}\text { Crushed the leaves of the plant with bulb of } \\
\text { A. sativum in by adding and take medicine orally } \\
\text { for three days }\end{array}$ & oral & \\
\hline & & & & & Flue & $\begin{array}{l}\text { Leaf of } R \text {. chalepensis is pounded with bulb of } \\
\text { A. Sativum, mixed with soup and used as a drink }\end{array}$ & oral & \\
\hline Sansevieria erythraeae Mattei & Dracenaceae & Eka termo & Shrub & Leaf & Ear infection & $\begin{array}{l}\text { Leaves are heated on fire, juice squeezed into tea } \\
\text { cup and three to four drops are added into the } \\
\text { infected ear }\end{array}$ & inner & SA01365 \\
\hline \multirow[t]{2}{*}{ Schinus molle L } & \multirow[t]{2}{*}{ Anacardiaceae } & \multirow[t]{2}{*}{ Tselim berbere } & \multirow[t]{2}{*}{ Tree } & Stem & Blood pressure & Chewing the stem & oral & \multirow[t]{2}{*}{ SA01364 } \\
\hline & & & & Leaf & Eye infection & $\begin{array}{l}\text { Boil leaves in water and let the patient bath himself } \\
\text { with steam }\end{array}$ & oral & \\
\hline Solanum hirtulum Steud. ex A. Rich. & Solanaceae & Alalemo kelbi & Herb & Root & Stomach ache & Chewing the root & oral & SA01393 \\
\hline \multirow[t]{2}{*}{ Solanum incanum L. } & \multirow[t]{2}{*}{ Solonaceaee } & \multirow[t]{2}{*}{ Neshtey engule } & \multirow[t]{2}{*}{ Shrub } & Leaf & Anthrax & $\begin{array}{l}\text { Seven leaves are crushed, mixed with honey and } \\
\text { taken orally }\end{array}$ & oral & \multirow[t]{2}{*}{ SA01372 } \\
\hline & & & & Root & Arthritis & $\begin{array}{l}\text { Roots are ground, powder mixed with animal butter } \\
\text { and cream applied on affected body part and let } \\
\text { the patient expose himself to sun light for five days }\end{array}$ & Dermal & \\
\hline
\end{tabular}


Table 1 List of medicinal plants used to treat human diseases (Continued)

\begin{tabular}{|c|c|c|c|c|c|c|c|c|}
\hline & & & & & Stomach ache & Chewing the root & Dermal & \\
\hline & & & & & Gonorrhoea & $\begin{array}{l}\text { Roots are ground, powder mixed with honey and } \\
\text { paste taken for five days }\end{array}$ & oral & \\
\hline Solanum marginatum L. f. & Solanaceae & Abyiengule & Shrub & Seed & Tuberculosis & $\begin{array}{l}\text { Seeds are dried, crushed and added into milk or } \\
\text { coffee and solution taken every morning for } 21 \text { days }\end{array}$ & oral & SA01313 \\
\hline \multirow[t]{2}{*}{ Solanum nigrum $\mathrm{L}$. } & Solanaceae & Alalemo Wezero & Shrub & Leaf & Epistaxis & Leaves crushed and pasted on the nasal openings & Dermal & SA01360 \\
\hline & & & & & $\begin{array}{l}\text { Bleeding after } \\
\text { delivery }\end{array}$ & Leaves are crushed and inserted into vagina & Dermal & \\
\hline Tagetes minuta $\mathrm{L}$. & Asteraceae & Etsefaruos & Herb & Whole plant & Evil eye & Smoking the plant and let the patient fumigate himself & nasal & SA01389 \\
\hline Tragia uncinata M. Gilbert & Euphorbiaceae & Amae & Herb & Root & Impotence & $\begin{array}{l}\text { Roots are ground and taken orally with local soup } \\
\text { for a week }\end{array}$ & oral & SA01361 \\
\hline \multirow[t]{2}{*}{ Trigonella foenum-graecum L. } & Fabaceae & Aba'ke & Herb & Seed & Urticaria & $\begin{array}{l}\text { Grind seeds, mix powder with butter and apply } \\
\text { cream on affected part }\end{array}$ & dermal & SA01392 \\
\hline & & & & & Stomach ache & Boil powder in water, add sugar and given to babies & oral & \\
\hline \multirow[t]{4}{*}{ Verbascum sinaiticum Benth. } & Scrophulariaceae & Trnaka & Herb & Leaf & Bleeding & Leaves are crushed and paste applied on affected area & dermal & SA01366 \\
\hline & & & & & Haemorrhoids & $\begin{array}{l}\text { Leaves are crushed, packed in a piece of cloth and } \\
\text { inserted through rectum }\end{array}$ & rectal & \\
\hline & & & & & Fire burn & $\begin{array}{l}\text { Leaves are crushed, squeezed and juice applied on } \\
\text { the damaged part using clean cotton }\end{array}$ & dermal & \\
\hline & & & & & Swelling & Rub the swelling using fresh leaves & dermal & \\
\hline \multirow[t]{7}{*}{$\begin{array}{l}\text { Verbena officinalis subsp. africana } \\
\text { R. Fernandes \& Verdc. }\end{array}$} & Verbenaceae & Atush & Herb & Whole plant & Ascariasis & $\begin{array}{l}\text { Plant is crushed, squeezed and juice taken with cup } \\
\text { of coffee for three days }\end{array}$ & & SA01307 \\
\hline & & & & & Diarrhoea & $\begin{array}{l}\text { Plant is crushed, squeezed and juice taken with cup } \\
\text { of coffee for two to three days }\end{array}$ & oral & \\
\hline & & & & Leaf & Ear infection & $\begin{array}{l}\text { Leaves are crushed, squeezed, juice filtered with } \\
\text { clean cotton cloth, juice mixed with goat butter } \\
\text { and three drops are added into the infected ear }\end{array}$ & auricular & \\
\hline & & & & & Herpes zoster & Leaves are crushed and paste applied on affected area & Dermal & \\
\hline & & & & Root & Snake bite & Chewing the root & oral & \\
\hline & & & & & Tonsillitis & $\begin{array}{l}\text { Adults chew the root and spit paste into the mouth } \\
\text { of their sick child }\end{array}$ & oral & \\
\hline & & & & Whole plant & $\begin{array}{l}\text { abdominal pain } \\
\text { and febrile illness }\end{array}$ & $\begin{array}{l}\text { Plant is crushed, squeezed and solution taken with } \\
\text { the cup of tea }\end{array}$ & oral & \\
\hline \multirow[t]{2}{*}{ Vernonia amygdalina Del. } & Asteraceae & Grawa & Tree & Leaf, root & Devil sickness & $\begin{array}{l}\text { Rub body with crushed leaves or smoke root and } \\
\text { inhale the smoke. Crushed young twigs and leaves } \\
\text { may also be spread in a house }\end{array}$ & Dermal/nasal & SA01306 \\
\hline & & & & Leaf & Malaria & $\begin{array}{l}\text { Crushed leaves of this plant and } R \text {. Chalepensis are } \\
\text { boiled and three tablet- sized medicine prepared by }\end{array}$ & oral & \\
\hline
\end{tabular}


Table 1 List of medicinal plants used to treat human diseases (Continued)

\begin{tabular}{|c|c|c|c|c|c|c|c|c|}
\hline & & & & & & $\begin{array}{l}\text { mixing paste with honey is served every morning } \\
\text { for seven days }\end{array}$ & & \\
\hline & & & & Root & Snake bite & Chewing the root & oral & \\
\hline & & & & Leaf & Teeth ache & Leaves are chewed with bulbs of $A$. sativum & oral & \\
\hline Withania somnifera (L.) Dunal & Solanaceae & Agoal & Shrub & Leaf, stem & michi & $\begin{array}{l}\text { Leaves and stems of the plant are decocted with } \\
\text { leaves of } E \text {. globulus and } C \text {. africana and patient } \\
\text { takes steam nasally }\end{array}$ & nasal & SA01356 \\
\hline Zehneria scabra (Linn.f.) Sond. & Cucurbitaceae & Haregressa & Herb & Whole plant & Febrile illness & $\begin{array}{l}\text { The plant together with E. globulus and } \\
J \text {. schimperiana is boiled in water and patient } \\
\text { takes steam nasally }\end{array}$ & Nasal & SA01305 \\
\hline Zingiber officinale Rosc. & Zingiberaceae & gengible & Herb & Rhizome & Blood pressure & Chewing the rhizome & Oral & SA01399 \\
\hline Ziziphus spina-christi (L.) Desf. & Rhamnaceae & geba & Shrub & Whole plant & Dandruff & Leaves are crushed and paste applied on head skin & Dermal & SA01370 \\
\hline
\end{tabular}


Table $\mathbf{2}$ List of medicinal plants used to treat livestock diseases

\begin{tabular}{|c|c|c|c|c|c|c|c|c|c|}
\hline Scientific name & Family & Local name & Habit & $\begin{array}{l}\text { Parts } \\
\text { used }\end{array}$ & Disease treated & $\begin{array}{l}\text { Animal } \\
\text { treated }\end{array}$ & Mode of preparation and administration & $\begin{array}{l}\text { Application } \\
\text { route }\end{array}$ & $\begin{array}{l}\text { Voucher } \\
\text { no }\end{array}$ \\
\hline \multirow[t]{10}{*}{ Aloe megalacantha Baker } & \multirow[t]{10}{*}{ Aloaceae } & \multirow[t]{10}{*}{ Ere } & \multirow[t]{10}{*}{ Shrub } & \multirow[t]{2}{*}{ Exudate } & Anthrax & Cattle & $\begin{array}{l}\text { Crush leaves, squeeze the exudate, mix it } \\
\text { with cold water let the animal drink one } \\
\text { cup of the solution }\end{array}$ & Oral & SA01384 \\
\hline & & & & & Trypanosomiasis & Cattle & $\begin{array}{l}\text { Exudate is mixed with poultry faeces is } \\
\text { smeared on affected body parts }\end{array}$ & Dermal & \\
\hline & & & & Root & Dislocation of body parts & Cattle & $\begin{array}{l}\text { Roots are cut into pieces, tied by thread } \\
\text { and tied on damaged part of the body }\end{array}$ & Dermal & \\
\hline & & & & \multirow[t]{7}{*}{ Exudate } & \multirow[t]{4}{*}{ Wound } & Cattle & \multirow{4}{*}{$\begin{array}{l}\text { Exudate is smeared on affected body } \\
\text { part of the animal }\end{array}$} & \multirow[t]{4}{*}{ Dermal } & \\
\hline & & & & & & Equine & & & \\
\hline & & & & & & Sheep & & & \\
\hline & & & & & & Goat & & & \\
\hline & & & & & \multirow[t]{3}{*}{ Scabies } & Cattle & \multirow{3}{*}{$\begin{array}{l}\text { Crush leaves and apply exudate on the } \\
\text { infected skin }\end{array}$} & \multirow[t]{3}{*}{ Dermal } & \\
\hline & & & & & & Sheep & & & \\
\hline & & & & & & Goat & & & \\
\hline \multirow[t]{2}{*}{ Achyranthes aspera $\mathrm{L}$. } & \multirow[t]{2}{*}{ Amaranthaceae } & \multirow[t]{2}{*}{ Muchelo } & \multirow[t]{2}{*}{ Herb } & \multirow[t]{2}{*}{ Root } & \multirow[t]{2}{*}{ Thelaziasis (eye disease) } & Cattle & \multirow{2}{*}{$\begin{array}{l}\text { Roots are chewed and juice spitted into } \\
\text { the affected eye of cattle }\end{array}$} & \multirow[t]{2}{*}{ Eye } & \multirow[t]{2}{*}{ SA01303 } \\
\hline & & & & & & Equine & & & \\
\hline \multirow[t]{8}{*}{ Allium sativum $\mathrm{L}$. } & \multirow[t]{8}{*}{ Alliaceae } & \multirow[t]{8}{*}{ Tsada shugurti } & \multirow[t]{8}{*}{ Herb } & \multirow[t]{8}{*}{ Bulb } & \multirow[t]{2}{*}{ Thelaziasis (eye disease) } & Cattle & \multirow{2}{*}{$\begin{array}{l}\text { Bulbs are crushed, squeezed, filtered, } \\
\text { mixed with soot and paste inserted into } \\
\text { affected part }\end{array}$} & \multirow[t]{2}{*}{ Eye } & \multirow[t]{8}{*}{ SA01368 } \\
\hline & & & & & & Equine & & & \\
\hline & & & & & \multirow[t]{4}{*}{ Aspergillosis } & Cattle & Crush bulb with leaves of Leucas sp., & Nasal & \\
\hline & & & & & & Equine & $\begin{array}{l}\text { squeezed it, add sa } \\
\text { cup of the juice }\end{array}$ & & \\
\hline & & & & & & Sheep & & & \\
\hline & & & & & & Goat & & & \\
\hline & & & & & Foot and mouth disease & Cattle & $\begin{array}{l}\text { Allium sativum is crushed, mixed with } \\
\text { honey and apply paste on affected part }\end{array}$ & Dermal & \\
\hline & & & & & Newcastle disease & Poultry & $\begin{array}{l}\text { Bulb is crushed, mixed with 'enjera' and } \\
\text { is orally administered }\end{array}$ & Oral & \\
\hline Argemone mexicana $\mathrm{L}$. & Pappavaraceae & Medafe tilian & Herb & Leaf & Sore & Camel & Leaves are pounded into powder and & Dermal & SA01381 \\
\hline & & & & & & Equine & washing it with salted water & & \\
\hline & & & & & & Cattle & & & \\
\hline Calpurnia aurea (Alt.) Benth. & Fabaceae & Hetsawets & Tree & Seed & Salmonellosis & Cattle & A cup of seeds are ground, powder & Oral & SA01345 \\
\hline & & & & & & Sheep & solution given orally administered & & \\
\hline & & & & & & Goat & & & \\
\hline
\end{tabular}


Table 2 List of medicinal plants used to treat livestock diseases (Continued)

\begin{tabular}{|c|c|c|c|c|c|c|c|c|c|}
\hline & & & & \multirow[t]{6}{*}{ Leaf } & \multirow[t]{3}{*}{ E. coli infection } & Cattle & \multirow{3}{*}{$\begin{array}{l}\text { Leaves are crushed, squeezed, filtered } \\
\text { and juice is orally administered }\end{array}$} & \multirow[t]{3}{*}{ Oral } & \\
\hline & & & & & & Sheep & & & \\
\hline & & & & & & Goat & & & \\
\hline & & & & & $\begin{array}{l}\text { Lichen simplex chronicus } \\
\text { (skin disease) }\end{array}$ & Cattle & Leaves are crushed and rubbed on the skin & Dermal & \\
\hline & & & & & Sheep pox & Sheep & Leaves are crushed and rubbed on the skin & Dermal & \\
\hline & & & & & & Goat & & & \\
\hline \multirow[t]{4}{*}{ Calotropis procera (Ait.) Ait. } & \multirow[t]{4}{*}{ Asclepidaceae } & \multirow[t]{4}{*}{ Ginda } & \multirow[t]{4}{*}{ Shrub } & \multirow[t]{4}{*}{ Latex } & \multirow[t]{4}{*}{ Sore } & Cattle & \multirow[t]{4}{*}{ Latex smeared on affected area until cure } & \multirow[t]{4}{*}{ Dermal } & \multirow[t]{4}{*}{ SA01375 } \\
\hline & & & & & & Equine & & & \\
\hline & & & & & & Sheep & & & \\
\hline & & & & & & Goat & & & \\
\hline \multirow[t]{3}{*}{ Croton macrostachyus Del. } & \multirow[t]{3}{*}{ Euphorbiaceae } & \multirow[t]{3}{*}{ Tanbuk } & \multirow[t]{3}{*}{ Tree } & \multirow[t]{3}{*}{ Leaves } & \multirow[t]{3}{*}{ Scabies } & Cattle & \multirow{3}{*}{$\begin{array}{l}\text { Leaf of } C \text {. macrostachyus is crushed and } \\
\text { rubbed on the affected skin three to four } \\
\text { days consecutively }\end{array}$} & \multirow[t]{3}{*}{ Dermal } & \multirow[t]{3}{*}{ SA01373 } \\
\hline & & & & & & Goat & & & \\
\hline & & & & & & Sheep & & & \\
\hline \multirow[t]{6}{*}{ Cucumis ficifolius A. Rich. } & \multirow[t]{6}{*}{ Cucurbitaceae } & \multirow[t]{6}{*}{ rambo Rambo } & \multirow[t]{6}{*}{ Shrub } & \multirow[t]{6}{*}{ Root } & \multirow[t]{4}{*}{ infection } & Equine & \multirow{4}{*}{$\begin{array}{l}\text { Roots is crushed into powder, mixed } \\
\text { with cold water and a cup of solution } \\
\text { is given orally }\end{array}$} & \multirow[t]{4}{*}{ Oral } & SA01321 \\
\hline & & & & & & Cattle & & & \\
\hline & & & & & & Sheep & & & \\
\hline & & & & & & Goat & & & \\
\hline & & & & & Hyena bite & Equine & Root is crushed, mixed with 'tella', & Dermal & \\
\hline & & & & & & Cattle & 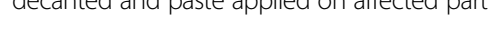 & & \\
\hline $\begin{array}{l}\text { Cyphostemma adenocaule } \\
\text { (steud.ex A. Rich) Descoings } \\
\text { ex Wild and Drummond }\end{array}$ & Vitaceae & $\begin{array}{l}\text { Aserkuka } \\
\text { fetahkuka }\end{array}$ & Climber & Root & Pack sore & Equine & $\begin{array}{l}\text { Roots are crushed, dried, ground and } \\
\text { powder sprinkled on affected part until } \\
\text { sore dries }\end{array}$ & Dermal & SA01346 \\
\hline Dodonaea angustifolia L. f. & Sapindaceae & Tahsos & Shrub & Leaf & Sore on cattle & Equine & Leaves are dried on hot iron plate, ground & Dermal & SA01327 \\
\hline & & & & & and equ & Cattle & and powder spread on affected part & & \\
\hline & & & & & & Sheep & & & \\
\hline & & & & & & Goat & & & \\
\hline & & & & Twig & Dislocation of & Cattle & Dislocated part is tied with twigs & Dermal & \\
\hline & & & & & & Equine & umint medied & & \\
\hline & & & & & & Sheep & & & \\
\hline & & & & & & Goat & & & \\
\hline Eucalyptus globulus Labill. & Myrtaceae & Tsada kelamitos & Tree & Leaf & Avian cholera & Poultry & $\begin{array}{l}\text { Leaf of } E \text {. globulus is ground, powder } \\
\text { boiled in water, solution added onto } \\
\text { barely soup and fed to chicken }\end{array}$ & Oral & SA01376 \\
\hline
\end{tabular}


Table 2 List of medicinal plants used to treat livestock diseases (Continued)

\begin{tabular}{|c|c|c|c|c|c|c|c|c|c|}
\hline Euphorbia cactus Boiss & Euphorbiaceae & Kolqual hamat & Shrub & Latex & Black leg & Cattle & $\begin{array}{l}\text { Apply latex on the swollen part to protect } \\
\text { the spread of the disease. Latex is also } \\
\text { given in small amount with 'enjera' }\end{array}$ & Dermal, oral & SA01386 \\
\hline \multirow{6}{*}{$\begin{array}{l}\text { Justicia schimperiana } \\
\text { (Hochst. ex A.Nees) T. Anders }\end{array}$} & \multirow[t]{6}{*}{ Acanthaceae } & \multirow[t]{6}{*}{ Shemeza } & \multirow[t]{6}{*}{ Shrub } & Leaf, root & \multirow[t]{2}{*}{ Blackleg } & \multirow[t]{2}{*}{ Cattle } & \multirow{2}{*}{$\begin{array}{l}\text { Leaf and root of } J \text {. schimperiana is } \\
\text { pounded with dried fruit of Ricinus } \\
\text { communis. One bottle of the Solution } \\
\text { is given to sick animal }\end{array}$} & \multirow[t]{2}{*}{ Oral } & \multirow[t]{6}{*}{ SA01301 } \\
\hline & & & & Leaf & & & & & \\
\hline & & & & & \multirow[t]{4}{*}{ Parasites } & Cattle & \multirow{4}{*}{$\begin{array}{l}\text { Pounded leaf of J. schimperiana is mixed } \\
\text { with malt powder of barely and two to } \\
\text { three glass of 'tella' given to the animal }\end{array}$} & \multirow[t]{4}{*}{ Oral } & \\
\hline & & & & & & Equine & & & \\
\hline & & & & & & Goat & & & \\
\hline & & & & & & Sheep & & & \\
\hline \multirow[t]{7}{*}{ Lepidium sativum $\mathrm{L}$. } & \multirow[t]{7}{*}{ Brassicaceae } & \multirow[t]{7}{*}{ Shenfa } & \multirow[t]{7}{*}{ Herb } & \multirow[t]{7}{*}{ Seed } & Dysentery & cattle & \multirow{3}{*}{$\begin{array}{l}\text { Seeds are crushed, powder mixed with } \\
\text { finger milt bread and orally administered }\end{array}$} & \multirow[t]{3}{*}{ Oral } & \multirow[t]{7}{*}{ SA01310 } \\
\hline & & & & & & sheep & & & \\
\hline & & & & & & goat & & & \\
\hline & & & & & cenoresis & sheep & Crushed seed of L. sativum and bulb of & Oral & \\
\hline & & & & & & goat & $\begin{array}{l}\text { A. sativum is are mixed with cold water } \\
\text { and a cup of solution is given to the animal }\end{array}$ & & \\
\hline & & & & & Diarrhoea & Cattle & $\begin{array}{l}\text { Seed of Lepidium sativum are ground, } \\
\text { powdered mixed with crushed bulb of } \\
\text { A. sativum and given to the animal }\end{array}$ & Dermal & \\
\hline & & & & & Bloating & Cattle & $\begin{array}{l}\text { Seed of } L \text {. sativum and bulb of Allium sativum } \\
\text { are crushed together, mixed with water and } \\
\text { given to cattle }\end{array}$ & Dermal & \\
\hline \multirow{2}{*}{$\begin{array}{l}\text { Leucas abyssinica (Benth.) } \\
\text { Briq. }\end{array}$} & \multirow[t]{2}{*}{ Lamiaceae } & \multirow[t]{2}{*}{ Sewa Kerni } & \multirow[t]{2}{*}{ Shrub } & \multirow[t]{2}{*}{ Leaf } & \multirow[t]{2}{*}{ Internal parasites } & Sheep & \multirow{2}{*}{$\begin{array}{l}\text { Leaves are crushed and squeezed, mixed } \\
\text { with crushed bulb of Allium sativum, } \\
\text { solution is then filtered and applied nasally }\end{array}$} & \multirow[t]{2}{*}{ Nasal } & \multirow[t]{2}{*}{ SA01383 } \\
\hline & & & & & & Goat & & & \\
\hline \multirow[t]{4}{*}{ Premna oligotricha L. } & \multirow[t]{4}{*}{ Lamiaceae } & Sasa hadima & Shrub & Leaf & Internal parasites & Sheep & Leaves are crushed, squeezed and given & Nasal & SA01325 \\
\hline & & & & & & Goat & & & \\
\hline & & & & Leaf & Pasterellosis & Sheep & Leaves are pounded with bulb of $A$. sativum, & Nasal & \\
\hline & & & & & & Goat & squeezed and sol & & \\
\hline Linum usitatissimum L. & Lineaaceae & Entatie & H.erb & Seed & Placental retention & Cattle & Seeds of L. usitatissimum are powdered & Oral & SA01386 \\
\hline & & & & & & Sheep & water and given to cattle & & \\
\hline & & & & & & Goat & & & \\
\hline Melia azedarach L. & Meliaceae & $\mathrm{Nim}$ & Tree & Leaf & Tick ulcer & Cattle & Leaves are rushed and rubbed on & Dermal & SA01382 \\
\hline & & & & & & Sheep & & & \\
\hline & & & & & & Goat & & & \\
\hline
\end{tabular}


Table 2 List of medicinal plants used to treat livestock diseases (Continued)

\begin{tabular}{|c|c|c|c|c|c|c|c|c|c|}
\hline \multirow[t]{3}{*}{ Nicotiana glauca R. Grah. } & \multirow[t]{3}{*}{ Solanaceae } & \multirow{3}{*}{$\begin{array}{l}\text { Tenbish/ } \\
\text { cherged }\end{array}$} & \multirow[t]{3}{*}{ Shrub } & \multirow[t]{3}{*}{ Leaf } & \multirow[t]{3}{*}{ External parasites } & Cattle & \multirow{3}{*}{$\begin{array}{l}\text { Leaves crushed and rubbed on the skin of } \\
\text { the animal }\end{array}$} & \multirow[t]{3}{*}{ Dermal } & \multirow[t]{3}{*}{ SA01391 } \\
\hline & & & & & & Sheep & & & \\
\hline & & & & & & Goat & & & \\
\hline \multirow[t]{6}{*}{ Nicotiana tabacum L. } & \multirow[t]{6}{*}{ Solanaceae } & \multirow[t]{6}{*}{ Tumbako } & \multirow[t]{6}{*}{ Herb } & \multirow[t]{3}{*}{ Leaf, root } & \multirow[t]{3}{*}{ Plant toxin (toxicosis) } & Cattle & \multirow{3}{*}{$\begin{array}{l}\text { Leaves and root are dried, powdered, mixed } \\
\text { with salted water and a cup of the solution is } \\
\text { given for one day the poisoned animal }\end{array}$} & \multirow[t]{3}{*}{ Oral } & \multirow[t]{6}{*}{ SA01308 } \\
\hline & & & & & & Goat & & & \\
\hline & & & & & & Sheep & & & \\
\hline & & & & \multirow[t]{3}{*}{ Leaf } & Leech infestation & Cattle & $\begin{array}{l}\text { Leaves are crushed, squeezed and a cup of } \\
\text { solution is nasally applied }\end{array}$ & Nasal & \\
\hline & & & & & Leech infestation & Cattle & $\begin{array}{l}\text { Crushed and baked leaves are pounded, } \\
\text { added on half litre of water and given to } \\
\text { affected animal }\end{array}$ & Oral & \\
\hline & & & & & Trypanosomiasis & Cattle & $\begin{array}{l}\text { Leaves are crushed and baked, mixed with } \\
\text { water and solution given to sick animal }\end{array}$ & Oral & \\
\hline \multirow[t]{5}{*}{ Otostegia integrifolia Benth. } & \multirow[t]{5}{*}{ Lamiaceae } & \multirow[t]{5}{*}{ Cheendog } & \multirow[t]{5}{*}{ Shrub } & \multirow{5}{*}{$\begin{array}{l}\text { Whole } \\
\text { plant }\end{array}$} & \multirow{5}{*}{$\begin{array}{l}\text { Ecto- parasites } \\
\text { infestation }\end{array}$} & Cattle & \multirow{5}{*}{$\begin{array}{l}\text { Fumigate the plant in the house where the } \\
\text { animals are kept }\end{array}$} & \multirow[t]{5}{*}{ Dermal } & \multirow[t]{5}{*}{ SA01357 } \\
\hline & & & & & & Equine & & & \\
\hline & & & & & & Poultry & & & \\
\hline & & & & & & Goat & & & \\
\hline & & & & & & Sheep & & & \\
\hline \multirow{6}{*}{$\begin{array}{l}\text { Phytolacca dodecandra } \\
\text { L'Herit. }\end{array}$} & \multirow[t]{6}{*}{ Phytolaccaceae } & \multirow[t]{6}{*}{ Shebti } & Shrub & Leaf & Rabies & Cattle & Leaves are crushed with leaves of & Oral & SA01387 \\
\hline & & & & & & Equine & $\begin{array}{l}\text { c. mycrostachyus, squeezed and a cup of } \\
\text { juice mixed with 'tella' is given to the animal }\end{array}$ & & \\
\hline & & & & & & Sheep & & & \\
\hline & & & & & & Goat & & & \\
\hline & & & & & $\begin{array}{l}\text { Scabies and external } \\
\text { parasite infestation }\end{array}$ & $\begin{array}{l}\text { Cattle } \\
\text { sheep }\end{array}$ & $\begin{array}{l}\text { Leaves are crushed with little water and } \\
\text { paste rubbed on the skin. The skin is then } \\
\text { washed after thirty minutes }\end{array}$ & Dermal & \\
\hline & & & & & & Goat & & & \\
\hline Rhoicissus tridentata (L. f.) & Vitaceae & Hareg temen & Climber & Root/ & Snake bite & Cattle & Root /stem is crushed, squeezed, mixed with & Oral & SA01344 \\
\hline & & & & & & Goat & $\begin{array}{l}\text { cold water and a cup of solution is given only } \\
\text { once to the animal }\end{array}$ & & \\
\hline & & & & & & Sheep & & & \\
\hline & & & & & & Equine & & & \\
\hline Ricinus communis L. & Euphobiaceae & Gulie & Shrub & Root & Sudden Sickness & Cattle & $\begin{array}{l}\text { Roots of } R \text {. communis and Justica schimperiana } \\
\text { are pounded, mixed with cold water and a } \\
\text { cup of the solution is to the sick animal }\end{array}$ & Oral & SA01377 \\
\hline & & & & Fruit & Anthrax & Cattle & $\begin{array}{l}\text { Dried fruits are ground, powder mixed with } \\
\text { cold water and a cup of solution is given the } \\
\text { sick animal }\end{array}$ & Oral & \\
\hline
\end{tabular}


Table 2 List of medicinal plants used to treat livestock diseases (Continued)

\begin{tabular}{|c|c|c|c|c|c|c|c|c|c|}
\hline & & & & \multirow[t]{3}{*}{ Root } & \multirow[t]{3}{*}{ Actinomycosis } & Cattle & \multirow{3}{*}{$\begin{array}{l}\text { Root is pounded by adding table salt and } \\
\text { ash and mixed with water, solution is filtered } \\
\text { and two glasses of it are to the sick animal }\end{array}$} & \multirow[t]{3}{*}{ Oral } & \\
\hline & & & & & & Sheep & & & \\
\hline & & & & & & Goat & & & \\
\hline & & & & \multirow[t]{4}{*}{ Fruit } & \multirow[t]{4}{*}{ Epizoitic lymphagities } & Cattle & \multirow{4}{*}{$\begin{array}{l}\text { Dried fruits are pounded and mixed with } \\
\text { exudate of Aloe megalacantha and paste } \\
\text { applied on ulcerated skin }\end{array}$} & \multirow[t]{4}{*}{ Dermal } & \\
\hline & & & & & & Equine & & & \\
\hline & & & & & & Sheep & & & \\
\hline & & & & & & Goat & & & \\
\hline \multirow[t]{3}{*}{ Rhamnus prinoides L'Herit. } & \multirow[t]{3}{*}{ Rhamnaceae } & \multirow[t]{3}{*}{ Gesh } & \multirow[t]{3}{*}{ Shrub } & \multirow[t]{3}{*}{ Leaf } & \multirow[t]{3}{*}{ Plant toxin (toxicosis) } & Cattle & \multirow{3}{*}{$\begin{array}{l}\text { Leaves are crushed into powdered and } \\
\text { mixed with malt of barely or oil or dissolved } \\
\text { soap and one or two cups of the solution } \\
\text { is given to the poisoned animal }\end{array}$} & \multirow[t]{3}{*}{ Oral } & \multirow[t]{3}{*}{ SA01350 } \\
\hline & & & & & & Sheep & & & \\
\hline & & & & & & Goat & & & \\
\hline Ruta chalepensis L. & Rutaceae & Chena adam & Herb & Leaf & Coccsidiosis & Poultry & $\begin{array}{l}\text { Whole part of the plant, root of J. schimperiana } \\
\text { and bark of C. mycrostachyus are pounded } \\
\text { together and paste given to chicken by mixing } \\
\text { it 'enjera' or water }\end{array}$ & Oral & SA01380 \\
\hline \multirow[t]{3}{*}{ Salvia schimperi Benth. } & \multirow[t]{3}{*}{ Lamiaceae } & \multirow[t]{3}{*}{ Meshendedo } & \multirow[t]{3}{*}{ Herb } & \multirow[t]{3}{*}{ Leaf } & \multirow[t]{3}{*}{ Foot and mouth disease } & Cattle & \multirow{3}{*}{$\begin{array}{l}\text { Leaves are crushed, mixed with honey and } \\
\text { dressed on the affected part of the animal }\end{array}$} & \multirow[t]{3}{*}{ Dermal } & \multirow{3}{*}{ SA01355 } \\
\hline & & & & & & Goat & & & \\
\hline & & & & & & Sheep & & & \\
\hline \multirow[t]{6}{*}{ Solanum marginatum L. f. } & \multirow[t]{6}{*}{ Solonaceae } & \multirow[t]{6}{*}{ Abiyi engule } & \multirow[t]{6}{*}{ Shrub } & \multirow[t]{6}{*}{ Fruit } & \multirow[t]{3}{*}{ Urinary retention } & Cattle & \multirow{3}{*}{$\begin{array}{l}\text { Fruits are crushed, pounded, two to three } \\
\text { spoons of powder is mixed with cold water } \\
\text { and a cup of solution is given to the } \\
\text { sick animal }\end{array}$} & \multirow[t]{3}{*}{ Oral } & SA01313 \\
\hline & & & & & & Sheep & & & \\
\hline & & & & & & Goat & & & \\
\hline & & & & & Tuberculosis & Cattle & Fruits are crushed, pounded, two to three & Oral & \\
\hline & & & & & & Sheep & $\begin{array}{l}\text { spoons of powder is mixed with cold water } \\
\text { and a cup of solution is given to the sick }\end{array}$ & & \\
\hline & & & & & & Goat & animal until recovery & & \\
\hline
\end{tabular}




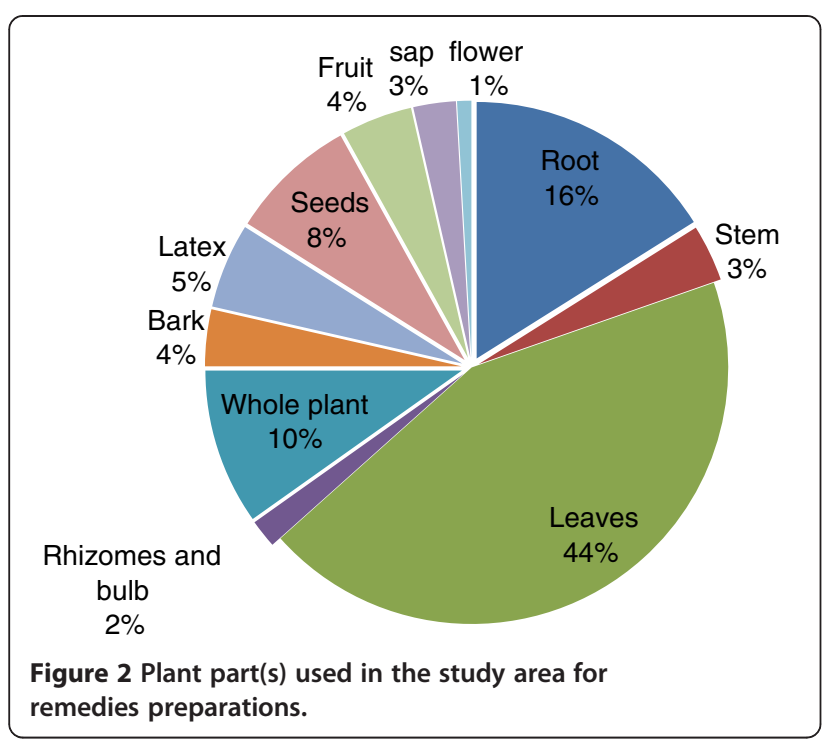

whole plants (10\%) and seeds (8\%) (Figure 2). Crushing (37\%), pounding (15\%) and chewing (13\%) were dominantly used in the preparation of remedies (Figure 3). Substances such as cold water, honey, coffee, butter, salt, sugar, soap, ash and milk were mixed with the plant materials during remedies preparations. The majority (60\%) of remedies were prepared from fresh plant materials. Some $(21.1 \%)$ were prepared from either dry or fresh materials and others (18.9\%) from dry parts only.

\section{Route of remedy administration and dosage}

Most medicinal plant preparations were applied internally (64.6\%), out of which drinking took the lead (44.5\%). Some are applied externally on the skin (35.4\%), of which $42.5 \%$ are smeared on the skin $(42.5 \%)$ (Table 3 ). Informants reported that dosages differed among
Table 3 Route of administration of remedies

\begin{tabular}{|c|c|c|}
\hline Main route of application & Mode of application & $\begin{array}{l}\text { Percent } \\
\text { applied }\end{array}$ \\
\hline \multicolumn{3}{|l|}{ Internal application } \\
\hline & drinking & 44.5 \\
\hline & chewing and swallowing & 17 \\
\hline & swallowing & 12 \\
\hline & Smoke bath & 9.6 \\
\hline & nasal & 6 \\
\hline & auricular & 3 \\
\hline & ophthalmic & 2 \\
\hline & Steam bath & 2 \\
\hline & anal & 1.4 \\
\hline & Buried & 1.4 \\
\hline & Total & 100 \\
\hline \multicolumn{3}{|l|}{ External application } \\
\hline & Smearing & 42.5 \\
\hline & pasting & 20 \\
\hline & rubbing & 12.5 \\
\hline & spraying & 7.5 \\
\hline & Chewing and spitting & 7.5 \\
\hline & washing & 6 \\
\hline & tying & 3.8 \\
\hline & Total & 100 \\
\hline
\end{tabular}

traditional medicine practitioners even in treating the same health problem as remedies are prescribed with units of local measurement such as pinch, tea spoon (powder), tablet size of seed (semisolid), coffee cup, tea cup and water cup (liquid), finger length (root) and fist (leaves).

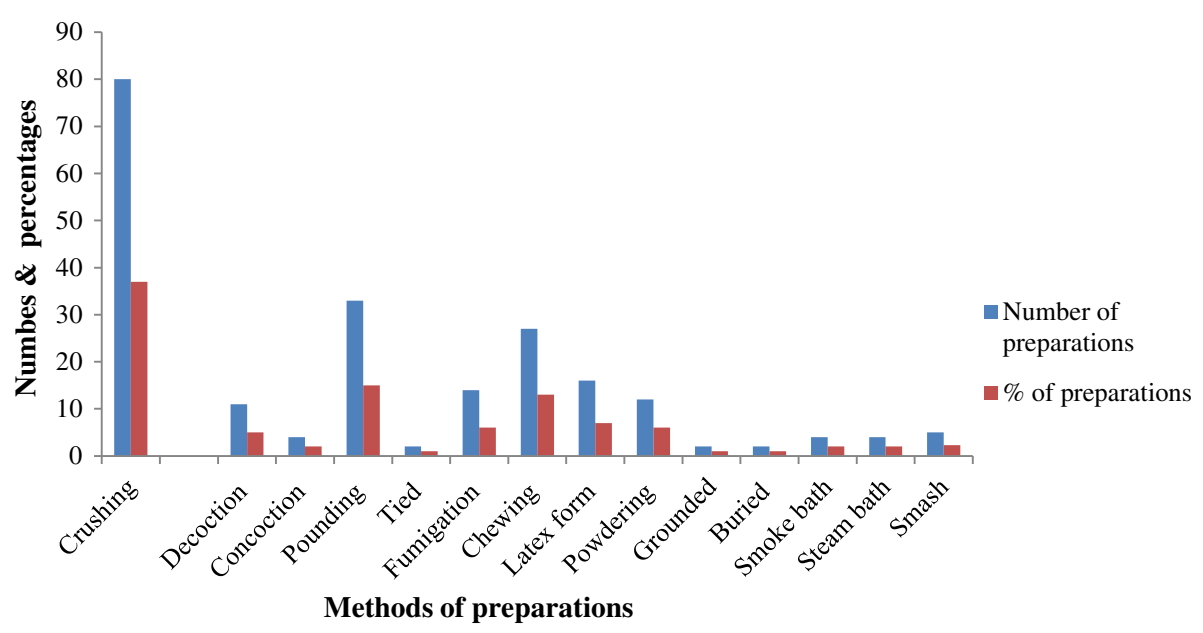

Figure 3 Preparation methods of remedies. 


\begin{tabular}{ll}
$\begin{array}{l}\text { Table } 4 \text { Medicinal plants with highest informants' } \\
\text { consensus }\end{array}$ & $\begin{array}{l}\text { Number (\%) of informants } \\
\text { who cited the plant }\end{array}$ \\
\hline Botanical name & $54(81.8)$ \\
\hline Cucumis ficifolius & $51(77)$ \\
Allium sativum & $50(75.8)$ \\
Croton macrostachyus & $50(75.8)$ \\
Ruta chalepensis & $50(75.8)$ \\
Vebena officinalis subsp. africana & $48(72.7)$ \\
Aloe megalocantha & $48(72.7)$ \\
Calotropis procera & $48(72.7)$ \\
Datura stramonium & $48(72.7)$ \\
Ocimum lamiifolium & $48(72.7)$ \\
Solanum incanum & $47(71)$ \\
Phytolacca dodecandra & $46(69.7)$ \\
Eucalyptus globulus & $46(69.7)$ \\
Olea europaea subsp. cuspidata & $46(69.7)$ \\
Plumbago zeylanica & $46(69.7)$ \\
Rhoicissus tridentata & $46(69.7)$ \\
Zehneria scabra & $45(68)$ \\
Cynoglossum coeruleum & $45(68)$ \\
Lepidium sativum & $45(68)$ \\
Withania somnifera &
\end{tabular}

\section{Popularity of reported medicinal plants}

Cucumis ficifolius is the most popular medicinal plant in the study area, cited by $81.8 \%$ of the informants, followed by Allium sativum (77\%). Each of the medicinal plants Croton marcostachyus, Ruta chalepensis and Vebena officinalis were cited by $75.8 \%$ of the informants (Table 4 ).

\section{Informant consensus factor}

Febrile illness is the disease group in the study area that scored the highest ICF value (0.97), followed by cardiovascular problems (0.97), evil eye (0.95), hepatitis (0.95), warts and haemorrhoids (0.94), infectious wounds and scabies (0.92), snake and scorpion bites (0.92), fungal diseases (0.91) and intestinal parasites infection, diarrhoea and stomach ache (0.91) and malaria (0.91) (Table 5).

\section{Informants' preference on medicinal plants used to treat snake bite \\ Preference ranking exercises of six selected informants indicate that Rhoicissus tridentata was the most pre- ferred plant in treating snake bite, followed by Nicotiana tabacum (Table 6).}

\section{Multipurpose medicinal plants}

The people in the study district relied on locally growing plant species for various purposes such as construction,

Table 5 Informant consensus factor (ICF) values for aliments categories

\begin{tabular}{|c|c|c|c|c|c|}
\hline Disease categories & No. of species & Species (\%) & No. of use citations & Use citations (\%) & ICF \\
\hline Abdominal irritation and vomiting & 4 & 4.4 & 23 & 1 & 0.86 \\
\hline Bleeding and epistaxis & 3 & 3.3 & 17 & .8 & 0.88 \\
\hline Cardiovascular problems & 5 & 5.6 & 85 & 3.7 & 0.95 \\
\hline Evil eye & 15 & 16.7 & 287 & 12.6 & 0.95 \\
\hline Fungal diseases & 14 & 15.6 & 138 & 6 & .91 \\
\hline Head and tooth aches & 8 & 8.9 & 60 & 2.6 & 0.88 \\
\hline Hepatitis & 7 & 7.8 & 122 & 5 & 0.95 \\
\hline Infectious wounds and scabies & 23 & 25.6 & 260 & 11 & 0.92 \\
\hline Intestinal parasites infection, diarrhoea and stomach ache & 26 & 28.9 & 281 & 12 & 0.91 \\
\hline Malaria & 8 & 8.9 & 79 & 3.5 & 0.91 \\
\hline Febrile illness & 8 & 8.9 & 231 & 10 & 0.97 \\
\hline Non infectious swelling & 10 & 11.1 & 87 & 3.7 & 0.89 \\
\hline Respiratory disease & 16 & 17.8 & 136 & 6 & 0.89 \\
\hline Rheumatism and arthritis & 15 & 16.7 & 105 & 4.6 & 0.87 \\
\hline Sensorial disease & 11 & 12.2 & 102 & 4 & 0.90 \\
\hline Snake and scorpion bites & 8 & 8.8 & 91 & 4 & 0.92 \\
\hline Urinary and placental retention & 6 & 6.7 & 50 & 2.2 & 0.90 \\
\hline Venereal disease and reproductive organ problems & 12 & 13.3 & 72 & 3 & 0.86 \\
\hline Warts and haemorrhoids & 8 & 8.9 & 111 & 4.9 & 0.94 \\
\hline
\end{tabular}


Table 6 Preference ranking on selected plants used against snake bite

\begin{tabular}{lllllllllll}
\hline Medicinal plants & \multicolumn{10}{c}{ Respondents $(\mathbf{A}-\mathbf{H})$} \\
\cline { 2 - 11 } & A & B & C & D & E & F & G & H & Total & Rank \\
\hline Cucumis ficifolius & 3 & 2 & 1 & 4 & 3 & 2 & 3 & 5 & 23 & 6th \\
Gossypium herbaceum & 3 & 2 & 4 & 5 & 4 & 2 & 3 & 4 & 27 & 5 th \\
Nicotiana tabacum & 5 & 3 & 4 & 5 & 5 & 3 & 3 & 4 & 32 & 2nd \\
Rhoicissus tridentata & 6 & 5 & 3 & 6 & 5 & 5 & 4 & 3 & 37 & 1 st \\
Verbena officinalis & 6 & 3 & 2 & 4 & 3 & 3 & 2 & 5 & 28 & 4 th \\
Vernonia amygdalina & 5 & 4 & 4 & 3 & 5 & 2 & 4 & 3 & 30 & 3 rd \\
\hline
\end{tabular}

firewood, medicine, charcoal, fencing, agricultural tool and furniture. Direct matrix ranking exercise performed on five commonly reported multipurpose medicinal plants shows that Olea europaea subsp. cuspidata was the most useful multipurpose plant, followed by Cordia africana (Table 7).

\section{Habitats of and threats to medicinal plants}

The majority (60.2\%) of medicinal plants were collected from the wild. Some (29\%) were also collected from both farmlands and roadsides (Figure 4).

According to reports of informants, agricultural expansion is considered as number one threat to the survival of medicinal plants in the study area, followed by, cutting of trees for charcoal and fire wood consumption (Table 8).

\section{Marketed medicinal plants}

Local market survey carried out in three towns of the District, namely Samre, Wenberta Adekeala and Fina Rewa revealed that plants were not sold in the markets for their sole medicinal purpose. The medicinal plants Klinia odora, Lepidium sativum, Allium sativum, Rumex abyssinicus, Plumbago zeylanica, Linum usitatissimum and Ruta chalepensis were sold primarily for their uses as species and food.

\section{Discussion}

It is encouraging to find out that a high number of medicinal plants (90 species) are still being used by people in Seharti Samre District of Tigray Region, northern Ethiopia, to treat several human and livestock diseases. Ethnobotanical studies conducted in Ofla and RayaAzebo districts of the same Region [6] came up with comparable numbers of medicinal plants, 83 and 60 species, respectively.

Several of the medicinal plants that were recorded from Seharti Samre District, were also mentioned in reports of studies previously conducted in Ethiopia, some of which (e.g. Aloe sp, Ficus palmata, Justica schimperiana, Lepidium sativum, Linum usitatissimum, Nicotiana tabacum, Otostegia integrifolia, Ricinus communis, Rumex abyssinicus, Ruta chalepensis and Zehneria scabra) $[6,19]$ were exactly used for same medicinal purposes, which could be an indication of their pharmacological effectiveness.

Analysis of the data revealed Solanaceae, Lamiaceae and Fabaceae as the highest contributors of medicinal plants in the Seharti Samre District, which could be a reflection of their dominance in the flora of Ethiopia and Eritrea $[20,21]$ in terms of their species richness. The study also showed that people in the study District use a relatively high number of shrubs and herbs, which is in agreement with studies conducted elsewhere in the country [22].

It was found out that two-third of medicinal plants in the study District were harvested from the wild, which is in agreement with reports of many studies conducted in the country $[6,23,24]$. Medicinal plants growing in the wild are highly exposed to different anthropogenic factors such as agricultural expansion, deforestation for

Table 7 Results of direct matrix ranking on selected multipurpose medicinal plants

\begin{tabular}{|c|c|c|c|c|c|}
\hline \multirow[b]{2}{*}{ Use category } & \multicolumn{5}{|l|}{ Species } \\
\hline & Croton macrostachyus & Cordia africana & Maesa lanceolata & Olea europaea subsp. cuspidata & Acokanthera schimperi \\
\hline Firewood & 2 & 3 & 3 & 4 & 3 \\
\hline Construction & 3 & 4 & 4 & 4 & 3 \\
\hline Charcoal & 2 & 2 & 3 & 4 & 2 \\
\hline Fencing & 2 & 2 & 2 & 2 & 3 \\
\hline Agricultural instrument & 4 & 3 & 3 & 4 & 1 \\
\hline Furniture & 2 & 4 & 3 & 4 & 1 \\
\hline Medicine & 4 & 3 & 4 & 4 & 4 \\
\hline Income source & 2 & 4 & 2 & 4 & 2 \\
\hline Total & 21 & 25 & 24 & 30 & 19 \\
\hline Rank & 4th & 2nd & $3 r d$ & $1 \mathrm{st}$ & 5th \\
\hline
\end{tabular}




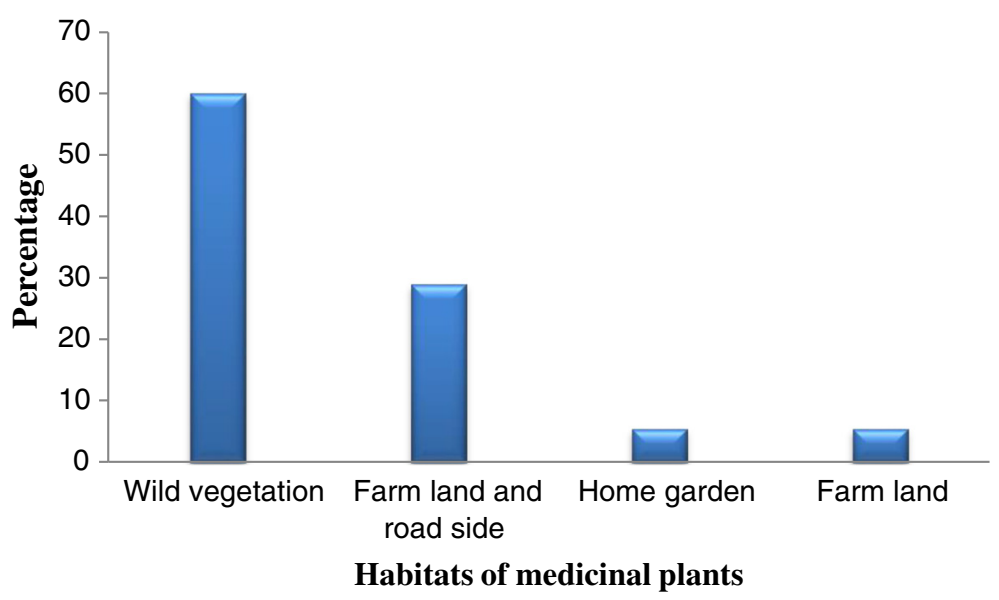

Figure 4 Habitats from which medicinal plants were collected.

charcoal and fire wood consumption, grazing, and harvesting for timber production and construction [22]. Olea europaea subsp. cuspidata, Maesa lanceolata, Cordia africana, Croton mycrostachyus, Acokanthera schimperi, Phytolacca dedocandra) are among the medicinal plants that were reported to be highly affected by the aforementioned factors.

Leaves and root were the most commonly used plant parts in the preparation of remedies in the study District. Many studies conducted in different parts of Ethiopia also showed that leaves are used more frequently than any other parts $[6,25,26]$. As compared to other parts, damage inflicted on medicinal plants due to harvest of leaves is very minimal [27].

Most of the medicinal plant species were reported to be processed through crushing followed by pounding and chewing. Ethnobotanical studies conducted in different parts of the country $[9,25,26]$ reported similar results. Majority of the remedies in the study District were reported to be taken internally/orally followed by smearing on the skin. Several studies conducted in different parts of the county [28] also revealed that oral followed by dermal were the principal routes of remedy administration.
One of the major problems in traditional medicine is lack of standard dosages and précised measurements [5]. According to informants in the study District, the amount of dosage prescribed for same/similar health problems vary as remedies are prescribed with different units of local measurement. Inconsistency of doses has also been reported in studies conducted elsewhere in Ethiopia [6,29,30].

The study revealed that informants above the age of 40 years had relatively better knowledge of medicinal plants as compared to the younger ones (20 to 40 years old). Similar study conducted among the Zay community in Ethiopia [24] revealed that $90 \%$ of the elders above 40 years of age had rich medicinal plant knowledge. Study conducted in Nigeria [31] reported that the highest percentage of younger generation had no any knowledge of traditional medicine practice due to more exposure to modern life style. This may demonstrate the impact of modernization on medicinal plant use and transfer of the associated knowledge to the younger generation. The fact that most of the knowledge on traditional medication is kept with elders for the sake of secrecy, gaining respect and generating income is believed

Table 8 Priority ranking of factors perceived as threats to medicinal plants

\begin{tabular}{|c|c|c|c|c|c|c|c|c|c|c|}
\hline \multirow[t]{2}{*}{ Factors } & \multicolumn{5}{|c|}{ Respondents (R1-R7) } & \multirow[b]{2}{*}{ R6 } & \multirow[b]{2}{*}{ R7 } & \multirow[b]{2}{*}{ Total } & \multirow[b]{2}{*}{$\%$} & \multirow[b]{2}{*}{ Rank } \\
\hline & $\mathrm{R} 1$ & $\mathrm{R} 2$ & R3 & R4 & $\overline{\mathrm{R} 5}$ & & & & & \\
\hline Agricultural expansion & 4 & 4 & 4 & 3 & 4 & 3 & 4 & 26 & 17.8 & $1 s t$ \\
\hline Charcoal and fire wood consumption & 4 & 3 & 4 & 4 & 3 & 3 & 3 & 24 & 16.4 & 2nd \\
\hline Grazing & 3 & 3 & 3 & 3 & 3 & 4 & 4 & 23 & 15.8 & $3 r d$ \\
\hline Settlement & 2 & 2 & 3 & 2 & 2 & 3 & 2 & 16 & 11 & 6th \\
\hline Timber and construction & 2 & 3 & 4 & 3 & 3 & 1 & 4 & 20 & 13.7 & 4 th \\
\hline Drought & 2 & 1 & 3 & 4 & 2 & 2 & 3 & 17 & 11.6 & 5 th \\
\hline Total & & & & & & & & 126 & & \\
\hline
\end{tabular}

Key: Values 1-4 were given: 1 is the least destructive threat and 4 is the most destructive threat. 
to contribute towards depletion of the same as generation passes by.

\section{Conclusion}

A total of 90 medicinal plants were reported by informants from the study District. As most of the medicinal plants were harvested from the wild, appropriate conservation measures are required to ensure their sustainable harvesting besides to efforts of aawareness creation among the community by concerned bodies regarding the usefulness of their medical plants. The efficacy and safety of the claimed medicinal plants need to be evaluated before recommending them for their wider use. Priority should be given to medicinal plants with the highest informant agreement as such plants are believed to have better activity.

\section{Competing interests}

The authors declare that they have no competing interests.

\section{Authors' contributions}

The three authors had significant intellectual contribution towards the design of the study, data collection and analysis and write-up of the manuscript. The authors read and approved the final manuscript.

\section{Acknowledgement}

The authors would like to acknowledge Jimma University for financial support, informants, local administration and people of Seharti Samre District for their positive response, sharing their valuable knowledge and time as well as for their tremendous hospitality. We also thank the following offices of the District: Rural Agricultural Development Office, Health Office, Administrative Office and Plan and Finance Office for their provision of data and supportive letter during data collection.

\section{Author details}

${ }^{1}$ Department of Biology, Jimma University, Jimma, Ethiopia. ${ }^{2}$ Aklilu Lemma Institute of Pathobiology, Addis Ababa University, Addis Ababa, Ethiopia.

\section{Received: 5 September 2014 Accepted: 28 February 2015}

Published online: 15 March 2015

\section{References}

1. Kaur R, Kapoor K, Kaur H. Plants as a source of anticancer agents. J Nat Prod Plant Resour. 2011;1:119-24.

2. Abebe D. Traditional medicine in Ethiopia. The attempt being made to promote it for effective and better utilization. SINET Ethiop J Sci. 1986;9:61-9.

3. WHO. WHO traditional medicine strategy 2002-2005. Geneva: World Health Organization (WHO); 2002.

4. Abebe D. The role of medicinal plants in health care coverage of Ethiopia the possible benefits of integration. In: Zewdu M, Demissie A, editors. Proceedings of the National Workshop on Conservation and Sustainable use of Medicinal Plants in Ethiopia: 28 April - 01 May 1998. Addis Ababa, Ethiopia: Institute of Biodiversity Conservation and Research; 2001. p. 6-21.

5. Abebe D, Ayehu A. Medicinal plant and enigmatic health practices of north Ethiopia. Addis Ababa, Ethiopia: Berhanina Selam Printing Enterprise; 1993.

6. Giday M, Ameni G. An ethnobotanical survey on plants of veterinary importance in two woredas of Southern Tigray, Northern Ethiopia. SINET Ethiop J Sci. 2003:26:123-36.

7. Yirga G. Assessment of indigenous knowledge of medicinal plants in Central Zone of Tigray, Northern Ethiopia. Afr J Plant Sci. 2010;4:6-11.

8. Yirga G. Assessment of traditional medicinal plants in Endrta District, South-eastern Tigray, Northern Ethiopia. Afr J Plant Sci. 2010:4:255-60.

9. Abdurhman N. Ethnobotanical study of medicinal plants used by local people in Ofla Wereda, Southern Zone of Tigray Region Ethiopia. Addis Ababa University: MSc thesis; 2010.
10. Yirga G, Teferi M, Brhane G, Amare S. Plants used in ethnoveterinary practices in Medebay-Zana District, Northern Ethiopia. J Med Plants Res. 2012;6:433-8.

11. Gebrezgabiher G, Kalayou S, Sahle S. An ethno-veterinary survey of medicinal plants in woredas of Tigray region, Northern Ethiopia. Int J Biodivers Conserv. 2013;5:89-97.

12. Teklay A, Abera B, Giday M. An ethnobotanical study of medicinal plants used in Kilte Awulaelo District, Tigray Region of Ethiopia. J Ethnobiol Ethnomed. 2013;9:65.

13. Zenebe G, Zerihun M, Solomon Z. An ethnobotanical study of medicinal plants in Asgede Tsimbila District, Northwestern Tigray, Northern Ethiopia. Ethnobotany Res Appl. 2012;10:305-20.

14. Gebremedhin B. Policies for sustainable land management in the highlands of Tigray, project objectives, activities, organization and database. In: Summary of papers and proceedings of a workshop. Mekelle, Ethiopia; 2002.

15. Alexiades MN. Collecting ethnobotanical data: an introduction to basic concepts and techniques. In: Alexiades MN, editor. Selected guidelines for ethnobotanical research: a field manual. New York: The New York Botanical Garden; 1996. p. 52-94.

16. Cotton CM. Ethnobotany: principles and applications. Chichester, England: John Wiley and Sons Ltd; 1996.

17. Heinrich M, Ankli A, Frei B, Weimann C, Sticher O. Medicinal plants in Mexico: Healers' consensus and cultural importance. Soc Sci Med. 1998:47:1859-71.

18. Martin GJ. Ethnobotany: a method manual. London: Chapman and Hall; 1995.

19. Ragunathan M, Mequanente S. Ethnomedicinal survey of folk drugs used Bahirdar Zuria district, North West, Ethiopia. Indian J Tradit Knowl. 2009:8:281-4.

20. Edwards S, Hedberg I, editors. Flora of Ethiopia and Eritrea, Volume 3: Pittosporaceae to Araliaceae. Addis Ababa, Ethiopia: The National Herbarium, Addis Ababa, Ethiopia, and Department of Systematic Botany, Uppsala, Sweden; 1989.

21. Hedberg I, Kelbessa E, Edwards S, Demissew S, Persson E, editors. Flora of Ethiopia and Eritrea, Volume 5: Gentianaceae to Cyclocheilaceae. Addis Ababa, Ethiopia: The National Herbarium, Addis Ababa, Ethiopia, and Department of Systematic Botany, Uppsala, Sweden; 2006.

22. Giday M, Teklehaymanot T, Animut A, Mekonnen Y. Medicinal plants of the Shinasha, Agew-Awi and Amhara peoples in northwest Ethiopia. J Ethnopharmacol. 2007;110:516-25.

23. Abebe D, Hagos E. Plants as a primary source of drugs in the traditional health practices of Ethiopia. In: Engles JMM, Hawkes JG, Worede M, editors. Plant genetic resources of Ethiopia. Cambridge: Cambridge University Press; 1991. p. 101-13.

24. Giday M, Asfaw Z, Emqvist T, Woldu Z. An ethnobotanical study of medicinal plants used by the Zay people in Ethiopia. J Ethnopharmacol. 2003:85:43-52.

25. Teshome $\mathbf{W}$. Impacts of urbanization on the traditional medicine of Ethiopia. Anthropol. 2005:8:43-52

26. Getaneh S, Girma Z. An ethnobotanical study of medicinal plants in Debre Libanos Wereda, Central Ethiopia. Afr J Plant Sci. 2014;8:366-79.

27. Yirga G. Use of traditional medicinal plants by indigenous people in Mekelle town, capital city of Tigray regional state of Ethiopia. J Med Plants Res. 2010:4:1799-804.

28. Birhane E, Aynekulu E, Mekuria W, Endale D. Management, use and ecology of medicinal plants in the degraded dry lands of Tigray, Northern Ethiopia. J Med Plants Res. 2011;5:309-18.

29. Bekele A, Musa A. Ethnoveterinary practice in Chiro District, western Hararge, Ethiopia. Pharmacologyonline. 2009;1:128-39.

30. Balemie K, Kelbessa E, Asfaw Z. Indigenous medicinal plant utilization, management and threats in Fentalle area, Eastern Shewa, Ethiopia. Ethiopian J Biol Sci. 2004;3:37-58.

31. Oladele A, Alade G, Omobuwajo O. Medicinal plants conservation and cultivation by traditional medicine practitioners (TMPs) in Aiyedaade local government area of Osun State, Nigeria. Agric Biol J N Am. 2011;2:476-87. 